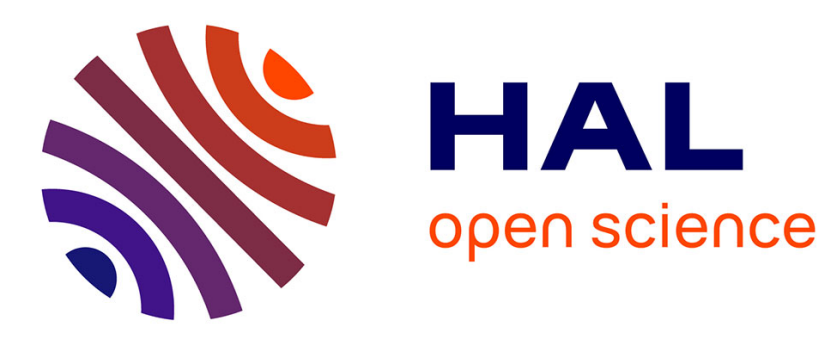

\title{
Autosomal recessive primary microcephaly due to ASPM mutations: An update
}

Pascaline Létard, Séverine Drunat, Yoann Vial, Sarah Duerinckx, Anais

Ernault, Daniel Amram, Stéphanie Arpin, Marta Bertoli, Tiffany Busa, Berten Ceulemans, et al.

\section{To cite this version:}

Pascaline Létard, Séverine Drunat, Yoann Vial, Sarah Duerinckx, Anais Ernault, et al.. Autosomal recessive primary microcephaly due to ASPM mutations: An update. Human Mutation, 2018, 39 (3), pp.319-332. 10.1002/humu.23381 . hal-02393637

\section{HAL Id: hal-02393637 \\ https://hal.science/hal-02393637}

Submitted on 4 Jan 2022

HAL is a multi-disciplinary open access archive for the deposit and dissemination of scientific research documents, whether they are published or not. The documents may come from teaching and research institutions in France or abroad, or from public or private research centers.
L'archive ouverte pluridisciplinaire $\mathbf{H A L}$, est destinée au dépôt et à la diffusion de documents scientifiques de niveau recherche, publiés ou non, émanant des établissements d'enseignement et de recherche français ou étrangers, des laboratoires publics ou privés. 


\section{Autosomal recessive primary microcephaly due to ASPM mutations: an}

\section{update}

Pascaline Létard ${ }^{1-3}$, Séverine Drunat ${ }^{1,4}$, Yoann Vial ${ }^{1,4}$, Sarah Duerinckx ${ }^{5}$, Anais Ernault ${ }^{4}$, Daniel Amram ${ }^{6}$, Stéphanie Arpin ${ }^{7}$, Marta Bertoli ${ }^{8}$, Tiffany Busa ${ }^{9}$, Berten Ceulemans ${ }^{10}$, Julie Desir $^{5}$, Martine Doco-Fenzy ${ }^{11}$, Siham Chafai Elalaoui ${ }^{12}$, Koenraad Devriendt ${ }^{13}$, Laurence Faivre $^{14}$, Christine Francannet ${ }^{15}$, David Geneviève ${ }^{16}$, Marion Gérard ${ }^{17}$, Cyril Gitiaux ${ }^{18}$, Sophie Julia $^{19}$, Sébastien Lebon ${ }^{20}$, Toni Lubala ${ }^{21}$, Michèle Mathieu-Dramard ${ }^{22}$, Hélène Maurey ${ }^{23}$, Julia Metreau ${ }^{23}$, Sanaa Nasserereddine ${ }^{24}$, Mathilde Nizon ${ }^{25}$, Geneviève Pierquin ${ }^{26}$, Nathalie Pouvreau $^{1,4}$, Clothilde Rivier-Ringenbach ${ }^{27}$, Massimiliano Rossi ${ }^{28}$, Elise Schaefer ${ }^{29}$, Abdelaziz Sefiani $^{12}$, Sabine Sigaudy ${ }^{9}$, Yves Sznajer ${ }^{30}$, Yusuf Tunca $^{31}$, Sophie Guilmin Crepon ${ }^{32,33}$, Corinne Alberti ${ }^{32,33}$, Monique Elmaleh-Bergès ${ }^{34}$, Brigitte Benzacken ${ }^{1,3,35}$, Bernd Wollnick ${ }^{36}$, C. Geoffrey Woods ${ }^{37}$, Anita Rauch ${ }^{38}$, Marc Abramowicz ${ }^{5}$, Vincent El Ghouzzi ${ }^{1}$, Pierre Gressens $^{1,39,40}$, Alain Verloes ${ }^{1}$, Sandrine Passemard* ${ }^{1,4,40}$

1 PROTECT, INSERM, Université Paris Diderot, Sorbonne Paris Cité, Paris, France.

2 Service d'Anatomie et de cytologie pathologiques, Hôpital Universitaire Jean Verdier, APHP, Bondy, France.

${ }^{3}$ Université Paris 13, Sorbonne Paris Cité, UFR de Santé, Médecine et Biologie Humaine, Bobigny, France.

${ }^{4}$ Département de Génétique, Hôpital Universitaire Robert Debré, APHP, Paris, France.

This article has been accepted for publication and undergone full peer review but has not been through the copyediting, typesetting, pagination and proofreading process, which may lead to differences between this version and the Version of Record. Please cite this article as doi: 10.1002/humu. 23381 .

This article is protected by copyright. All rights reserved. 
${ }^{5}$ Department of Medical Genetics, Hôpital Erasme and IRIBHM; Université Libre de Bruxelles, Brussels, Belgium.

${ }^{6}$ Unité de Génétique Clinique, Centre Hospitalier Intercommunal de Créteil, Créteil, France.

${ }^{7}$ Service de Génétique Clinique, Centre Hospitalier Régional Universitaire de Tours, Tours, France.

${ }^{8}$ Northern Genetics Service, Newcastle upon Tyne NHS Trust, Newcastle upon Tyne, UK.

${ }^{9}$ Service de Génétique Clinique, AP-HM, Hôpital Universitaire Timone Enfants, Marseille, France.

10 Department of Pediatric Neurology University Hospital and University of Antwerp, Belgium

${ }^{11}$ Service de Génétique, Centre Hospitalier Universitaire de Reims, Hôpital Maison blanche, et EA3801 SFR CAPSANTE, Reims, France.

12 Centre de Génomique Humaine, Faculté de médecine te de Pharmacie de Rabat, Université Mohamed V, Rabat, Morocco, and Département de Génétique Médicale, Institut National d'Hygiène, Rabat, Morocco.

${ }^{13}$ Center for Human Genetics, University of Leuven. Leuven, Belgium.

${ }^{14}$ Service de Génétique Médicale et Centre de Référence Anomalies du Développement et Syndromes Malformatifs, Centre Hospitalier Universitaire Dijon Bourgogne, Dijon, France.

${ }^{15}$ Service de Génétique Médicale, Centre Hospitalier Universitaire de Clermont-Ferrand, Clermont-Ferrand, France. 
${ }^{16}$ Département de Génétique Médicale, Maladies rares et Médecine Personnalisée, Centre Hospitalier Universitaire de Montpellier, Montpellier, France.

${ }^{17}$ Service de Génétique Clinique, Centre Hospitalier Universitaire de Caen, Caen, France.

${ }^{18}$ Département de neurologie pédiatrique, Hôpital Universitaire Necker Enfants Malades, APHP, Paris, France.

${ }^{19}$ Service de génétique médicale, Centre Hospitalier Universitaire de Toulouse, Toulouse, France.

${ }^{20}$ Unité de neuropédiatrie et neuroréhabilitation pédiatrique, Département Femme Mère Enfant, Lausanne University Hospital (CHUV), Lausanne, Switzerland.

${ }^{21}$ Department of Pediatrics, Sendwe University Hospitals, University of Lubumbashi, Lumbumbashi, DR Congo.

${ }^{22}$ Centre d’Activité Génétique Clinique et Oncogénétique, Centre Hospitalier Universitaire d'Amiens, Amiens, France.

${ }^{23}$ Service de neurologie pédiatrique, Hôpital Universitaire Bicêtre, Le Kremlin-Bicêtre, APHP, France.

${ }^{24}$ Laboratoire de génétique et pathologie moléculaire, Centre Hospitalier Universitaire Ibn Rochd, Casablanca, Morocco.

${ }^{25}$ Département de Génétique, Centre Hospitalier Universitaire de Nantes, Nantes, France

${ }^{26}$ Département de Génétique, Centre Hospitalier Universitaire de Liège, Liège, Belgique 
${ }^{27}$ Service de pédiatrie, Hôpital Nord Ouest-Villefranche, Gleize, France.

${ }^{28}$ Département de Génétique, Hospices Civils de Lyon, Lyon and INSERM U1028, CNRS UMR5292, Centre de Recherche en Neurosciences de Lyon, GENDEV Team, Université Claude Bernard Lyon 1, Bron, France.

29 Service de Génétique Médicale, Centre Hospitalier Universitaire de Strasbourg, Strasbourg, France.

${ }^{30}$ Centre for Human Genetics, Cliniques Universitaires Saint-Luc, Université Catholique de Louvain, Brussels, Belgium.

${ }^{31}$ Department of Medical Genetics, Gulhane School of Medicine, Gulhane Training and Research Hospital, University of Health Sciences, Etlik, Ankara, Turkey.

${ }^{32}$ Unité d’Epidémiologie Clinique, Hôpital Universitaire Robert Debré, APHP, Paris, France.

${ }^{33}$ Inserm, CIC-EC 1426, Université Paris Diderot, F-75019 Paris, France

${ }^{34}$ Service de radiologie, Hôpital Universitaire Robert Debré, APHP, Paris, France.

35 Laboratoire d'Histologie-Embryologie-Cytogénétique-BDR-CECOS, Hôpital Universitaire Jean Verdier, APHP, Bondy, France.

${ }^{36}$ Institut für Humangenetik, Universität Göttingen, Göttingen, Deutschland.

37 University of Cambridge, Cambridge Institute for Medical Research, Addenbrooke's Hospital, Cambridge, United Kingdom.

${ }^{38}$ Institute of Medical Genetics, University of Zurich, Schlieren-Zurich, Switzerland. 
39 Center for Developing Brain, King's College, St. Thomas' Campus, London, United Kingdom.

${ }^{40}$ Service de Neuropédiatrie, Hôpital Universitaire Robert Debré, APHP, Paris, France.

*Corresponding author:

Sandrine Passemard

Address: Inserm U1141, Hôpital Robert Debré, 48 Boulevard Sérurier, 75019, Paris, France.

E-mail: sandrine.passemard@inserm.fr

Phone: +331 40033691, Fax: +33140031995

Key Words: ASPM, centrosome, primary microcephaly, MCPH, brain development, brain imaging, intellectual disability 


\section{ABSTRACT}

Autosomal recessive microcephaly or MicroCephaly Primary Hereditary (MCPH) is a genetically heterogeneous neurodevelopmental disorder characterized by a reduction in brain volume, indirectly measured by an occipitofrontal circumference (OFC) 2 standard deviations or more below the age- and sex-matched mean (-2SD) at birth and -3SD after 6 months, and leading to intellectual disability of variable severity. The Abnormal SPindle-like Microcephaly gene (ASPM), the human ortholog of the Drosophila melanogaster 'abnormal spindle' gene (asp), encodes ASPM, a protein localized at the centrosome of apical neuroprogenitor cells and involved in spindle pole positioning during neurogenesis. Loss-offunction mutations in ASPM cause MCPH5, which affects the majority of all MCPH patients worldwide.

Here, we report 47 unpublished patients from 39 families carrying 28 new ASPM mutations, and conduct an exhaustive review of the molecular, clinical, neuroradiological and neuropsychological features of the 282 families previously reported (with 161 distinct ASPM mutations). Furthermore, we show that ASPM-related microcephaly is not systematically associated with intellectual deficiency and discuss the association between the structural brain defects (strong reduction in cortical volume and surface area) that modify the cortical map of these patients and their cognitive abilities. 


\section{Background}

Primary microcephaly (PM) refers to a group of autosomal recessive or dominant disorders characterized by a reduction in brain growth starting in utero, intellectual disability (ID) of variable severity, and the absence of extra-CNS malformations (Kaindl et al., 2009; Thornton \& Woods, 2009). The worldwide incidence of PM varies from $1: 30,000$ to $1: 250,000$ live births, depending on the geographic origin and mode of ascertainment (Komai, Kishimoto, \& Ozaki, 1955; Morris et al., 2016; Van Den Bosch, 1959). MCPH (Microcephaly primary hereditary) refers to a subtype of PM in which patients display an isolated primary microcephaly with nearly-normal brain cytoarchitecture, originally called "microcephalia vera". Nowadays, MCPH also includes primary microcephaly with cortical malformations. Clinically, MCPH is defined by an occipitofrontal circumference (OFC) that is 2 standard deviations (SD) or more below the age- and sex-matched mean at birth, and 3 SD or more below the mean after 6 months of age. MCPH might be detected from the $2^{\text {nd }}$ trimester of pregnancy by ultrasound scan (Woods \& Parker, 2013).

$\mathrm{MCPH}$ is genetically heterogeneous: an $\mathrm{MCPH}$ phenotype has been associated with mutations in at least 18 genes, MCPH1-18. Among them, ASPM (MCPH5 locus) is the most frequently mutated gene reported (Verloes, Drunat, Gressens, \& Passemard, 2013). Mutations in the remaining 17 genes cause less than $40 \%$ of the reported diagnosis. Many $\mathrm{MCPH}$ families have not been ascribed to any of the known genes, suggesting that additional MCPH genes are still to be discovered.

The Abnormal SPindle-like Microcephaly gene (ASPM; MIM\# 605481) is the human ortholog of the D. melanogaster 'abnormal spindle' gene (asp) and maps at the 1q31.3 locus (Bond et al., 2002; Jamieson, Fryns, Jacobs, Matthijs, \& Abramowicz, 2000; Pattison et al., 2000). Four 
isoforms have been described for the ASPM gene (Kouprina et al., 2005). The full length ASPM gene contains 28 exons and encodes a 3477 amino-acid protein localized to the spindle pole during metaphase and to the midbody during cytokinesis (Higgins et al., 2010; Kouprina et al., 2005; Paramasivam, Chang, \& LoTurco, 2007). ASPM plays a crucial role in the division of neural progenitor cells by keeping them cycling, promoting symmetric proliferative divisions at the expense of asymmetric neurogenic divisions (Fish, Kosodo, Enard, Paabo, \& Huttner, 2006). Different mouse models in which Aspm is knocked out reproduce the microcephaly observed in humans and show a reduction in cortical surface area (Capecchi \& Pozner, 2015; Pulvers et al., 2010). The mechanisms underlying Aspm microcephaly in mice are an increase in cell cycle duration in neural progenitors, many of which exit the cell cycle, thereby leading to the premature exhaustion of the neural progenitor pool, and a subsequent increase in the production of neurons of the lower cortical layers along with a reduction in upper layer neuron production (Capecchi \& Pozner, 2015). Whether these mechanisms also explain microcephaly in humans is still unknown.

The ASPM protein (Figure 1) contains an amino-terminal ASH (ASPM, SPD-2, Hydin) domain with a putative microtubule-binding function, found in proteins associated with cilia, flagella, the centrosome and the Golgi complex (Schou, Morthorst, Christensen, \& Pedersen, 2014), an Actin Binding Domain (ABD) comprising two calponin homology ( $\mathrm{CH}$ ) domains that bind one actin monomer in the filament (Stradal, Kranewitter, Winder, \& Gimona, 1998), a series of repeated calmodulin-binding IQ domains, an Armadillo-like domain, and a carboxyterminal region of unknown significance. Although ASPM is highly conserved across species, the variability of its calmodulin-binding IQ repeats is of peculiar interest: The human protein displays 81 calmodulin-binding IQ repeats at positions 1273 to 3234, whereas there are 61 
calmodulin-binding IQ repeats in mice and 24 calmodulin-binding IQ repeats in Drosophila (Bond et al., 2002; Kouprina et al., 2005; Kouprina et al., 2004). Although still a topic of debate, it has been proposed that the expansion of the cerebral cortex depends on the number of calmodulin-binding IQ repeats (Bond et al., 2002; Bond \& Woods, 2006; Kouprina et al., 2005; Kouprina et al., 2004; Ponting \& Jackson, 2005).

In vitro experiments have shown that the $\mathrm{N}$-terminal portion of ASPM, encoded by the first seven exons, is sufficient to induce ASPM localization to the spindle pole during metaphase, whereas the C-terminal domain, encoded by the last three exons, is required for its localization to the midbody during cytokinesis (Kouprina et al., 2005; Paramasivam et al., 2007).

Although a large number of patients with ASPM mutations have been reported (AbdelHamid et al., 2016b; Ahmad et al., 2016; Akbariazar et al., 2013; Al-Gazali \& Ali, 2010; Ariani et al., 2013; Bond et al., 2002; Bond et al., 2003; Darvish et al., 2010; Desir, Abramowicz, \& Tunca, 2006; Desir, Cassart, David, Van Bogaert, \& Abramowicz, 2008; Gul et al., 2006; Gul et al., 2007; Halsall, Nicholas, Thornton, Martin, \& Geoffrey Woods, 2010; Hashmi et al., 2010; Hu et al., 2014; Kousar et al., 2010; Kumar, Blanton, Babu, Markandaya, \& Girimaji, 2004; Muhammad et al., 2009; Nakamura et al., 2015; Nicholas et al., 2009; Papari et al., 2013; Passemard, Kaindl et al., 2009; Pichon, Vankerckhove, Bourrouillou, Duprez, \& Abramowicz, 2004; Rump et al., 2016; Saadi et al., 2009; Sajid Hussain et al., 2013; Shen et al., 2005; Tan et al., 2014; Wang, Khan, Han, \& Zhang, 2017), their developmental phenotype has been documented only in a minority of cases. However, ID (Passemard, 
Kaindl et al., 2009) and epilepsy (Shen et al., 2005) are the most frequently reported clinical findings in patients with ASPM mutations.

In the present review, we report 47 new patients (39 families), followed within the EuroMicro network, and present an exhaustive overview of all individuals with ASPM mutations described in the literature since the gene was identified, along with their molecular, clinical, radiological and neuropsychological features. In particular, this review reveals that microcephaly linked to ASPM is not always associated with ID.

\section{Mutations}

\section{Reported mutations}

From the original discovery of ASPM mutations (Bond et al., 2002) to July 2017, 161 mutations have been reported. Reports were collected using the PubMed library. The terms "ASPM", "MCPH5", "MCPH", "autosomal recessive microcephaly", "microcephaly primary hereditary" and "microcephalic dwarfism" were used as key words. No intragenic copy number variations have been reported in Decipher; only large rearrangements encompassing more than the ASPM gene have been reported. The 161 ASPM mutations have been identified in 638 affected individuals belonging to 282 families. All the mutations are depicted in Figure 1 and summarized in Supp. Table S1. These mutations are spread all along the coding sequence and include 147 exonic variations, 12 intronic variations and 2 large deletions encompassing several exons/introns. Exonic variations $(n=147)$ include73 nucleotide substitutions (leading to 69 nonsense mutations, 2 putative splicing mutations and 2 missense mutations), 65 deletions of 1 to few nucleotides (leading to 61 frameshift mutations and 4 nonsense mutations) and 9 duplications or insertions of one nucleotide 
(leading to frameshift mutations). Intronic variations $(n=12)$ include 10 nucleotide substitutions and 2 deletions of one nucleotide (all predicted to interfere with correct splicing). Frameshift and splice-site mutations are predicted to result in unstable RNA that would be degraded by nonsense-mediated RNA decay or in truncated protein synthesis. However, few experiments have been carried out to verify this hypothesis except for two mutations located in exon 24 (c.9754del; pArg3252Glufs*10) and in intron 25 (c.9984+1G>T; predicting the removal of the intron 25 splice donor site) (Higgins et al., 2010; Kouprina et al., 2005). In the first case, western blot analysis has revealed the presence of a truncated protein. In the second case, although the size and localization of ASPM were not affected, only weak expression of the protein was detected at the spindle pole. Among the 161 mutations described so far, three mutations recur frequently. The c.3978G>A mutation (allele frequency $=18 \%$ ) has been specifically reported in Turkish and Pakistani families (60 families). The c.9557C>G mutation has been reported exclusively in Pakistan (7 families). Both mutations suggest a founder effect. In contrast, the third mutation (c.7782_7783del), which represents $4 \%$ of all alleles, is reported in families of different geographic origins (Europe, Africa and Asia) and is also found in the present study with a high allele frequency (17\%). It may therefore correspond to a hotspot mutation.

\section{Unreported mutations, methods of identification, cohort}

Molecular analysis was performed within our "EuroMicro" European Network (including five partners in France, Belgium, Germany, Switzerland and the UK), between 2007 and 2017, using samples from patients referred for typical $\mathrm{MCPH}$, primary microcephaly with cortical malformation or microcephalic primordial dwarfism. The unique inclusion criterion was an 
OFC lower than 2 SD below the age- and sex-matched mean at birth and lower than 3 SD below the mean after 6 months of age, irrespective of the patient's stature. Exclusion criteria were: 1) a context of anoxia-ischemia at birth, 2) a diagnosis of infectious or toxic fetopathy, or 3) major associated malformations suggestive of syndromic microcephaly.

Mutation analysis was performed on DNA extracted from peripheral blood leucocytes using standard procedures. The coding sequence $+/-25$ base pairs of intron/exon boundaries of the ASPM gene were screened for variants either by Sanger Sequencing or Next Generation Sequencing.

In total, we genotyped 47 patients from 39 unrelated families. 15 index cases were born to consanguineous parents. Genotyping identified 18 published and 28 unpublished variants (Table 1 and Figure 1). The new variants included 17 frameshift mutations, 9 nonsense mutations and 2 splicing mutations, all likely resulting in truncated protein products. Using Alamut Software (Interactive Biosoftware, Rouen, France), the pathogenicity of the identified variants was predicted to result in a loss of ASPM function in all cases, even though functional tests are needed to definitively determine their real consequences. Likewise, the presence of additional variants in the genome cannot be ruled out. The molecular data are shown in Table 1 and Figure 1. All mutations have been declared in the Leiden Open Variation Database (databases.lovd.nl/shared/genes/ASPM).

\section{Epidemiology, phenotype}

Epidemiology: 685 patients have been reported so far: (47 from the present study +638 in the literature) from $321(39+282)$ families. Among those whose sex has been described, 229 $(28+201)$ are males and $182(19+163)$ are females (Sex ratio $M / F=1.3)$. Most families come 
from the Asian subcontinent and middle-east: Pakistan (167 families), Saudi Arabia (18), Egypt $(2+16)$ and Iran (13); $47(16+31)$ families are from Europe and 3 from the Americas (Figure 2).

Growth: Although affected patients are described as "microcephalic", accurate growth parameters (especially OFC) are poorly documented in the literature (reported in less than $3 \%$ of patients at birth and only for $26 \%$ of patients during childhood). Auxological data for the present study and those reported in the literature are summarized in Figure 3 , and include OFC, height, and weight at birth and after 6 years of age. For our European series, SD was calculated according to Sempé (Sempé M, 1979). For cases published previously, we used the SD values provided by the authors. When only absolute values were available, we used WHO Child Growth Standards and WHO Reference 2007.

Microcephaly related to ASPM mutations has exceptionally been reported during pregnancy in 2 families (Desir et al., 2008; Hu et al., 2014). In the present study, microcephaly was detected during the third trimester of pregnancy in 23 cases (Table 2) and from the second trimester in 2 cases. However, the impact of these early forms on intellectual prognosis is variable (see details for patients \#8,9, 13, 20 and 30 in Table 2 and the paragraph on “cognition").

Two features characterize the growth of ASPM-mutated patients: the reduction of OFC growth kinetics with age and preserved growth in height from birth, as shown in Figure 3. 
Development and clinical features: Walking without support is acquired around 20 months of age (+/- 11 months, range 10 to 66 months; data available for $n=32 / 42$ in the present study and for $n=20 / 605$ in the literature - children aged 18 months or more). 59\% walked prior to or at 18 months of age. Available data related to verbal skills are scarce and heterogeneous in the literature, yet language acquisition seems to be delayed. $17 \%$ of patients from the present study were able to make full sentences at 3 years of age (data available for $n=30 / 37$ - children aged 3 years or more). Behavioral disorders, such as hyperkinesia, impulsiveness and aggressiveness, were observed in 16 patients from the present study and 17 from the literature. Neurological examination may show pyramidal syndrome or even spasticity ( $n=4$ in the present study and $n=7$ in the literature). Ataxia and tremors have not been reported. Seizures have been reported in 47 patients (10/47, i.e. $21 \%$ in the present study and $n=37$ in the literature). They appeared during childhood (not before 6 months of age), and were usually sensitive to antiepileptic drugs. Some patients show hypo- and/or hyperpigmented spots (6 patients: \#3, \#25, \#27, \#30, \#32.1 and \#32.2). Malformations are rare and do not present a recurrent pattern: scoliosis ( 2 families: patients \#32.1, \#32.2 and \#37), middle ear hypoplasia (1 patient: \#19), preaxial polydactyly (1 patient: (Ahmad et al., 2016)), unilateral cystic kidney (1 patient: (Passemard, Titomanlio et al., 2009)), tricuspid insufficiency (1 family: (Ariani et al., 2013))]. Deafness (1 patient (Darvish et al., 2010), Guillain-Barré syndrome (1 patient (Passemard, Titomanlio et al., 2009)) and nystagmus (patient \#24.3) have been reported or noticed in the present study. Fatal issues have been reported three times in the literature: one patient died after acute myeloid leukemia (Al-Gazali \& Ali, 2010) and two children (3 and 9 years old) died without any reported explanation (Abdel-Hamid et al., 2016; Hashmi et al., 2016). The co-occurrence 
of two unrelated genetic diseases has been shown in 3 patients: one with a deletion of the STS gene (Abdel-Hamid et al., 2016), one with oculocutaneous albinism (Abdel-Hamid et al., 2016), and one with familial retinitis pigmentosa due to CLN3 mutations (patient \#21) .

Cognition: A major prognostic factor to take into account in microcephaly is, naturally, intellectual ability. Although ID, from mild to severe, has been systematically reported in patients with ASPM mutations neuropsychological assessment was performed in only $35 / 628$ patients in the literature (i.e. only $5.6 \%$, Figure 4). Among these 35 patients, a Full Scale Intellectual Quotient (FSIQ) was available for only 24 patients. The mean FSIQ was $54 \pm$ 8 (range 40 to 71 ). Despite their ID, we have previously shown that long-term memory in these patients is spared, suggesting that they are able to learn (Passemard et al., 2016). The remaining 11 were assessed by various motor and language skill assessments, which allowed the developmental quotient (DQ) to be estimated, with a mean value of $46 \pm 23$ (range 30 to 104).

In the present study, among 36 children aged of 3 years or more at the last examination, psychological evaluation was not possible for 11 children living outside Europe. Among the remaining families ( 25 patients), the parents of 14 children agreed to a neuropsychological assessment and their children cooperated. Wechsler tests were first proposed to all patients. These tests are universally accepted tools (translated into many languages) that allow for comparisons between patients from different countries. Six patients were unable to take the Wechsler tests. Therefore, neuropsychologists proposed developmental quotient (DQ) assessment, using specific tests (Stanford Binet, Borel-Maisonny, Bayley) that 
are not always internationally available, and only relevant in populations sharing the same language. The mean DQ was $58 \pm 15$ (range 34 to 95 , Figure $4 \mathrm{~B}$ and Table 2), similar to scores seen in the literature.

Eight patients were able to perform the different subtests of the Wechsler scales. As shown in Figure 4 and Table 2, the mean FSIQ was $64 \pm 10$ (range 50 to 82). As compared to the 24 FSIQ values reported in the literature, the FSIQ of patients in the present study was significantly higher (Figure 4A, $p<0.05$, un-paired T-test). The "age" factor could explain such a difference. Indeed, our patients are younger (average $=6.6 \mathrm{y}$ ) than those described in the literature (average $=11.3 y$ ). These patients may face problems with maintaining their cognitive abilities with time, as tasks become more and more difficult, or may reach the upper limit of their abilities earlier, during childhood or adolescence. The precocity of diagnosis and of appropriate rehabilitation, whose effectiveness also depends on the age factor, would also influence intellectual prognosis. Surprisingly, for 4 out of 5 children who underwent detailed neuropsychological assessment (patients \#2, 8, 13 and 34, Table 2), at least one subtest, verbal comprehension and/or nonverbal performance, was in the normal range, suggesting learning disabilities rather than ID. For three patients (patients \# 2, 8 and 34), a difference of 20 points or more between scores was highlighted, leading to a diagnosis of dyspraxia. Furthermore, one child (patient \#13; 5.5y) obtained scores within the normal range or the low average on all subtests and the FSIQ, thus excluding ID (Table 2 and Figure 4). To our knowledge, this is the first report of ASPM-mutated patients with normal intelligence.

Brain MRI: Brain magnetic resonance imaging was performed in 39/47 patients from the present study (83\%) and has been reported in 50/638 patients (8\%) in the literature. The 
most frequent anomalies were: gyral simplification in $71 / 89$ cases $(67 \%$ of the present study and $90 \%$ of those examined in the literature), corpus callosum abnormalities (shape, size etc.) in $38 / 89$ cases ( $31 \%$ of the present study and $52 \%$ in the literature), and middle to moderate cerebellar and/or pontine hypoplasia in $26 / 89$ cases ( $15 \%$ of the present study [including obvious vermis and cerebellar atrophy in patient \#21, who developed a late onset ceroid lipofuscinosis, typically known to induce such atrophy] and $40 \%$ in the literature). Such neuroradiological features are often undiscriminating in terms of diagnosis (Figure 5), since they are not specific either to $\mathrm{MCPH}$ or to a specific type of $\mathrm{MCPH}$. Some atypical features have also been described: polymicrogyria in 3 cases (patient \#23.1 with extensive bilateral posterior polymicrogyria and (Marchal et al.; Passemard, Kaindl et al., 2009)), and syringomyelia (patient \#17.1). Conventional imaging is thus not informative enough to orient diagnosis or to predict prognosis, except if it shows migration disorders associated with microcephaly, such as polymicrogyria, that may increase the risk of epilepsy. The reduction of brain volume in humans provides evidence for early neuronal and glial defects. The existence of polymicrogyria show that migration disorders are associated with proliferation defects in ASPM microcephaly.

\section{Genotype-phenotype correlation}

The vast majority of $A S P M$ mutations are nonsense or frameshift mutations, predictive of the synthesis of a truncated protein. No IQ is available for patients carrying the two missense mutations (Gul, 2006; Darvish, 2010; Ahmad, 2016; Kraemer 2016). Most ASPM mutations are private. Moreover, intra-familial variability is frequent. In our opinion, the available data 
are still too scarce to make any correlations, underlining the need for better characterization of this rare disease.

\section{Future prospects}

Major efforts have been made for the molecular diagnosis of $\mathrm{MCPH}$, and the implementation of NGS in clinical diagnosis has identified ASPM mutations as the principal cause of MCPH worldwide. Although the vast majority of ASPM mutations likely result in the loss of function of the protein product, systematic functional studies are still required to prove the pathogenicity of the variants, and not only refine our knowledge of the roles of this protein but determine whether all mutations have the same consequences or whether some have differential impacts on the cell. The high number of patients reported is also countered by the drastic lack of fine clinical descriptions, neurocognitive investigations and large-scale studies correlating anomalies of brain morphology with neurodevelopmental, cognitive and behavioral characteristics. Hence, we have only limited knowledge regarding the real intellectual abilities and their natural history in these patients, or their functional cortical organization and cortical maps. To obtain new insights into ASPM-specific brain defects, two different approaches to cortical structure should be considered: structural brain imaging and the neuropathological study of post mortem cases. Indeed, we have shown that the $50 \%$ average reduction in brain volume is caused by a major reduction of cortical grey and white matter volumes that are in contrast to the relative preservation of the volume of the brainstem and cerebellum (Passemard et al., 2016). This massive reduction in cortical volume and cortical surface preferentially affects the neocortex and 
spares the hippocampus and mesiotemporal cortices, involved in long-term memory tasks, concordant with the preserved mnesic functions of these patients (Passemard et al., 2016). The autonomy and social insertion of these patients as adults as well as genetic counseling for their families would benefit from improved knowledge of the structural and cognitive characteristics of the brain.

Many biological questions remain regarding the mechanisms underlying ASPMmicrocephaly in humans. Mouse models have confirmed that the Aspm gene plays a major role in cortical expansion, promoting the symmetric proliferative divisions of neural progenitors. It is now crucial to better understand the consequences of ASPM mutations, not only in terms of neuronal production in affected patients, but also in terms of the specification/differentiation of these neurons, their connectivity and obviously their function. Improving synaptic plasticity in these patients to enhance their cognitive abilities is a future scientific challenge.

\section{Acknowledgements, Funding}

We are grateful to Dr Sowmyalakshmi Rasika for relevant comments and language editing during the preparation of this manuscript.

This work was supported by the Délégation à la Recherche Clinique et à I'Innovation de I'Assistance Publique Hopitaux de Paris, the Institut National pour la Santé et la Recherche Médicale (Inserm), the Université Paris 7, DHU PROTECT, National and European grants (French National Research Agency Programme Hospitalier de Recherche Clinique [PHRC], grant agreement $n^{\circ}$ P100128 / IDRCB : 2010-A01481-38 ; ERA-NET E-Rare 2013, EuroMicro project, grant agreement $n^{\circ}$ ANR-13-RARE-0007-01).

This article is protected by copyright. All rights reserved. 


\section{References}

Abdel-Hamid, M. S., Ismail, M. F., Darwish, H. A., Effat, L. K., Zaki, M. S., \& Abdel-Salam, G. M. (2016a). Co-Occurrence of Primary Microcephaly Caused by a Novel Homozygous Aspm Mutation Along with X-Linked Ichthyosis in the Same Patient. Genet Couns, 27(1), 25-33.

Abdel-Hamid, M. S., Ismail, M. F., Darwish, H. A., Effat, L. K., Zaki, M. S., \& Abdel-Salam, G. M. (2016b). Molecular and phenotypic spectrum of ASPM-related primary microcephaly: Identification of eight novel mutations. Am J Med Genet A, 170(8), 2133-2140.

Ahmad, I., Baig, S. M., Abdulkareem, A. R., Hussain, M. S., Sur, I., Toliat, M. R., et al. (2016). Genetic heterogeneity in Pakistani microcephaly families revisited. Clin Genet.

Akbariazar, E., Ebrahimpour, M., Akbari, S., Arzhanghi, S., Abedini, S. S., Najmabadi, H., et al. (2013). A Novel Deletion Mutation in ASPM Gene in an Iranian Family with Autosomal Recessive Primary Microcephaly. Iran J Child Neurol, 7(2), 23-30.

Al-Gazali, L., \& Ali, B. R. (2010). Mutations of a country: a mutation review of single gene disorders in the United Arab Emirates (UAE). Hum Mutat, 31(5), 505-520.

Ariani, F., Mari, F., Amitrano, S., Di Marco, C., Artuso, R., Scala, E., et al. (2013). Exome sequencing overrides formal genetics: ASPM mutations in a case study of apparent $\mathrm{X}$-linked microcephalic intellectual deficit. Clin Genet, 83(3), 288-290.

Bond, J., Roberts, E., Mochida, G. H., Hampshire, D. J., Scott, S., Askham, J. M., et al. (2002). ASPM is a major determinant of cerebral cortical size. Nat Genet, 32(2), 316-320.

Bond, J., Scott, S., Hampshire, D. J., Springell, K., Corry, P., Abramowicz, M. J., et al. (2003). Proteintruncating mutations in ASPM cause variable reduction in brain size. Am J Hum Genet, 73(5), 1170-1177.

Bond, J., \& Woods, C. G. (2006). Cytoskeletal genes regulating brain size. Curr Opin Cell Biol, 18(1), 95-101.

Capecchi, M. R., \& Pozner, A. (2015). ASPM regulates symmetric stem cell division by tuning Cyclin E ubiquitination. Nat Commun, 6, 8763.

Darvish, H., Esmaeeli-Nieh, S., Monajemi, G. B., Mohseni, M., Ghasemi-Firouzabadi, S., Abedini, S. S., et al. (2010). A clinical and molecular genetic study of 112 Iranian families with primary microcephaly. J Med Genet, 47(12), 823-828.

Desir, J., Abramowicz, M., \& Tunca, Y. (2006). Novel mutations in prenatal diagnosis of primary microcephaly. Prenat Diagn, 26(10), 989.

Desir, J., Cassart, M., David, P., Van Bogaert, P., \& Abramowicz, M. (2008). Primary microcephaly with ASPM mutation shows simplified cortical gyration with antero-posterior gradient preand post-natally. Am J Med Genet A, 146A(11), 1439-1443.

Fish, J. L., Kosodo, Y., Enard, W., Paabo, S., \& Huttner, W. B. (2006). Aspm specifically maintains symmetric proliferative divisions of neuroepithelial cells. Proc Natl Acad Sci U S A, 103(27), 10438-10443.

Gul, A., Hassan, M. J., Mahmood, S., Chen, W., Rahmani, S., Naseer, M. I., et al. (2006). Genetic studies of autosomal recessive primary microcephaly in 33 Pakistani families: Novel sequence variants in ASPM gene. Neurogenetics, 7(2), 105-110.

Gul, A., Tariq, M., Khan, M. N., Hassan, M. J., Ali, G., \& Ahmad, W. (2007). Novel protein-truncating mutations in the ASPM gene in families with autosomal recessive primary microcephaly. $J$ Neurogenet, 21(3), 153-163.

Halsall, S., Nicholas, A. K., Thornton, G., Martin, H., \& Geoffrey Woods, C. (2010). Critical consequences of finding three pathogenic mutations in an individual with recessive disease. J Med Genet, 47(11), 769-770. 
Hashmi, J. A., Al-Harbi, K. M., Ramzan, K., Albalawi, A. M., Mehmood, A., Samman, M. I., et al. (2016). A novel splice-site mutation in the ASPM gene underlies autosomal recessive primary microcephaly. Ann Saudi Med, 36(6), 391-396.

Higgins, J., Midgley, C., Bergh, A. M., Bell, S. M., Askham, J. M., Roberts, E., et al. (2010). Human ASPM participates in spindle organisation, spindle orientation and cytokinesis. BMC Cell Biol, $11,85$.

Hu, H., Suckow, V., Musante, L., Roggenkamp, V., Kraemer, N., Ropers, H. H., et al. (2014). Previously reported new type of autosomal recessive primary microcephaly is caused by compound heterozygous ASPM gene mutations. Cell Cycle, 13(10), 1650-1651.

Jamieson, C. R., Fryns, J. P., Jacobs, J., Matthijs, G., \& Abramowicz, M. J. (2000). Primary autosomal recessive microcephaly: MCPH5 maps to 1q25-q32. Am J Hum Genet, 67(6), 1575-1577.

Kaindl, A. M., Passemard, S., Kumar, P., Kraemer, N., Issa, L., Zwirner, A., et al. (2009). Many roads lead to primary autosomal recessive microcephaly. Prog Neurobiol.

Komai, T., Kishimoto, K., \& Ozaki, Y. (1955). Genetic study of microcephaly based on Japanese material. Am J Hum Genet, 7(1), 51-65.

Kouprina, N., Pavlicek, A., Collins, N. K., Nakano, M., Noskov, V. N., Ohzeki, J., et al. (2005). The microcephaly ASPM gene is expressed in proliferating tissues and encodes for a mitotic spindle protein. Hum Mol Genet, 14(15), 2155-2165.

Kouprina, N., Pavlicek, A., Mochida, G. H., Solomon, G., Gersch, W., Yoon, Y. H., et al. (2004). Accelerated evolution of the ASPM gene controlling brain size begins prior to human brain expansion. PLoS Biol, 2(5), E126.

Kousar, R., Nawaz, H., Khurshid, M., Ali, G., Khan, S. U., Mir, H., et al. (2010). Mutation analysis of the ASPM gene in 18 Pakistani families with autosomal recessive primary microcephaly. J Child Neurol, 25(6), 715-720.

Kumar, A., Blanton, S. H., Babu, M., Markandaya, M., \& Girimaji, S. C. (2004). Genetic analysis of primary microcephaly in Indian families: novel ASPM mutations. Clin Genet, 66(4), 341-348.

Marchal, J. A., Ghani, M., Schindler, D., Gavvovidis, I., Winkler, T., Esquitino, V., et al. Misregulation of mitotic chromosome segregation in a new type of autosomal recessive primary microcephaly. Cell Cycle, 10(17), 2967-2977.

Morris, J. K., Rankin, J., Garne, E., Loane, M., Greenlees, R., Addor, M. C., et al. (2016). Prevalence of microcephaly in Europe: population based study. BMJ, 354, i4721.

Muhammad, F., Mahmood Baig, S., Hansen, L., Sajid Hussain, M., Anjum Inayat, I., Aslam, M., et al. (2009). Compound heterozygous ASPM mutations in Pakistani MCPH families. Am J Med Genet A, 149A(5), 926-930.

Nakamura, K., Inui, T., Miya, F., Kanemura, Y., Okamoto, N., Saitoh, S., et al. (2015). Primary microcephaly with anterior predominant pachygyria caused by novel compound heterozygous mutations in ASPM. Pediatr Neurol, 52(5), e7-8.

Nicholas, A. K., Swanson, E. A., Cox, J. J., Karbani, G., Malik, S., Springell, K., et al. (2009). The molecular landscape of ASPM mutations in primary microcephaly. J Med Genet, 46(4), 249253.

Papari, E., Bastami, M., Farhadi, A., Abedini, S. S., Hosseini, M., Bahman, I., et al. (2013). Investigation of primary microcephaly in Bushehr province of Iran: novel STIL and ASPM mutations. Clin Genet, 83(5), 488-490.

Paramasivam, M., Chang, Y. J., \& LoTurco, J. J. (2007). ASPM and citron kinase co-localize to the midbody ring during cytokinesis. Cell Cycle, 6(13), 1605-1612.

Passemard, S., Kaindl, A. M., Titomanlio, L., Gerard, B., Gressens, P., \& Verloes, A. (2009). Primary Autosomal Recessive Microcephaly. . GeneReviews at GeneTests. Medical Genetics Information Resource [database online]. Copyright, University of Washington, Seattle, 19972009.

Available at http://www.genetests.org. .

This article is protected by copyright. All rights reserved. 
Passemard, S., Titomanlio, L., Elmaleh, M., Afenjar, A., Alessandri, J. L., Andria, G., et al. (2009). Expanding the clinical and neuroradiologic phenotype of primary microcephaly due to ASPM mutations. Neurology, 73(12), 962-969.

Passemard, S., Verloes, A., Billette de Villemeur, T., Boespflug-Tanguy, O., Hernandez, K., Laurent, M., et al. (2016). Abnormal spindle-like microcephaly-associated (ASPM) mutations strongly disrupt neocortical structure but spare the hippocampus and long-term memory. Cortex, 74, 158-176.

Pattison, L., Crow, Y. J., Deeble, V. J., Jackson, A. P., Jafri, H., Rashid, Y., et al. (2000). A fifth locus for primary autosomal recessive microcephaly maps to chromosome 1q31. Am J Hum Genet, 67(6), 1578-1580.

Pichon, B., Vankerckhove, S., Bourrouillou, G., Duprez, L., \& Abramowicz, M. J. (2004). A translocation breakpoint disrupts the ASPM gene in a patient with primary microcephaly. Eur J Hum Genet, 12(5), 419-421.

Ponting, C., \& Jackson, A. P. (2005). Evolution of primary microcephaly genes and the enlargement of primate brains. Curr Opin Genet Dev, 15(3), 241-248.

Pulvers, J. N., Bryk, J., Fish, J. L., Wilsch-Brauninger, M., Arai, Y., Schreier, D., et al. (2010). Mutations in mouse Aspm (abnormal spindle-like microcephaly associated) cause not only microcephaly but also major defects in the germline. Proc Natl Acad Sci U S A, 107(38), 16595-16600.

Rump, P., Jazayeri, O., van Dijk-Bos, K. K., Johansson, L. F., van Essen, A. J., Verheij, J. B., et al. (2016). Whole-exome sequencing is a powerful approach for establishing the etiological diagnosis in patients with intellectual disability and microcephaly. BMC Med Genomics, 9, 7.

Saadi, A., Borck, G., Boddaert, N., Chekkour, M. C., Imessaoudene, B., Munnich, A., et al. (2009). Compound heterozygous ASPM mutations associated with microcephaly and simplified cortical gyration in a consanguineous Algerian family. Eur J Med Genet.

Sajid Hussain, M., Marriam Bakhtiar, S., Farooq, M., Anjum, I., Janzen, E., Reza Toliat, M., et al. (2013). Genetic heterogeneity in Pakistani microcephaly families. Clin Genet, 83(5), 446-451.

Schou, K. B., Morthorst, S. K., Christensen, S. T., \& Pedersen, L. B. (2014). Identification of conserved, centrosome-targeting ASH domains in TRAPPII complex subunits and TRAPPC8. Cilia, 3, 6.

Sempé M, P. G., Roy-Pernot MP. (1979). Auxologie-méthodes et séquences. Paris: Theraplix.

Shen, J., Eyaid, W., Mochida, G. H., Al-Moayyad, F., Bodell, A., Woods, C. G., et al. (2005). ASPM mutations identified in patients with primary microcephaly and seizures. J Med Genet, 42(9), 725-729.

Stradal, T., Kranewitter, W., Winder, S. J., \& Gimona, M. (1998). CH domains revisited. FEBS Lett, 431(2), 134-137.

Tan, C. A., del Gaudio, D., Dempsey, M. A., Arndt, K., Botes, S., Reeder, A., et al. (2014). Analysis of ASPM in an ethnically diverse cohort of 400 patient samples: perspectives of the molecular diagnostic laboratory. Clin Genet, 85(4), 353-358.

Thornton, G. K., \& Woods, C. G. (2009). Primary microcephaly: do all roads lead to Rome? Trends Genet, 25(11), 501-510.

Van Den Bosch, J. (1959). Microcephaly in the Netherlands: a clinical and genetical study. Ann Hum Genet, 23(2), 91-116.

Verloes, A., Drunat, S., Gressens, P., \& Passemard, S. (2013). Primary Autosomal Recessive Microcephalies and Seckel Syndrome Spectrum Disorders. [R]. GeneReviews, In R. A. Pagon, M. P. Adam, H. H. Ardinger, S. E. Wallace, A. Amemiya, L. J. H. Bean, ... K. Stephens, 1993 (Eds.). Seattle. .

Wang, R., Khan, A., Han, S., \& Zhang, X. (2017). Molecular analysis of 23 Pakistani families with autosomal recessive primary microcephaly using targeted next-generation sequencing. $J$ Hum Genet, 62(2), 299-304.

Woods, C. G., \& Parker, A. (2013). Investigating microcephaly. Arch Dis Child, 98(9), 707-713. 


\section{Figure Legends:}

Figure 1: Location of the known and novel mutations identified in the human ASPM gene and corresponding domains in the protein.

The mutations reported previously are shown on the upper arch. Mutations identified in the present study but already known are indicated by \#. Novel mutations from the present study are indicated directly on exons. Various symbols represent missense, nonsense, splice and frameshift mutations as indicated. Allelic frequency $(\mathrm{AF})$ is indicated if $>2 \%$. Abbreviations: $A F=$ allelic frequency; $A S H=$ ASPM,SPD-2,Hydin; $\mathrm{CH}=$ calponin homology.

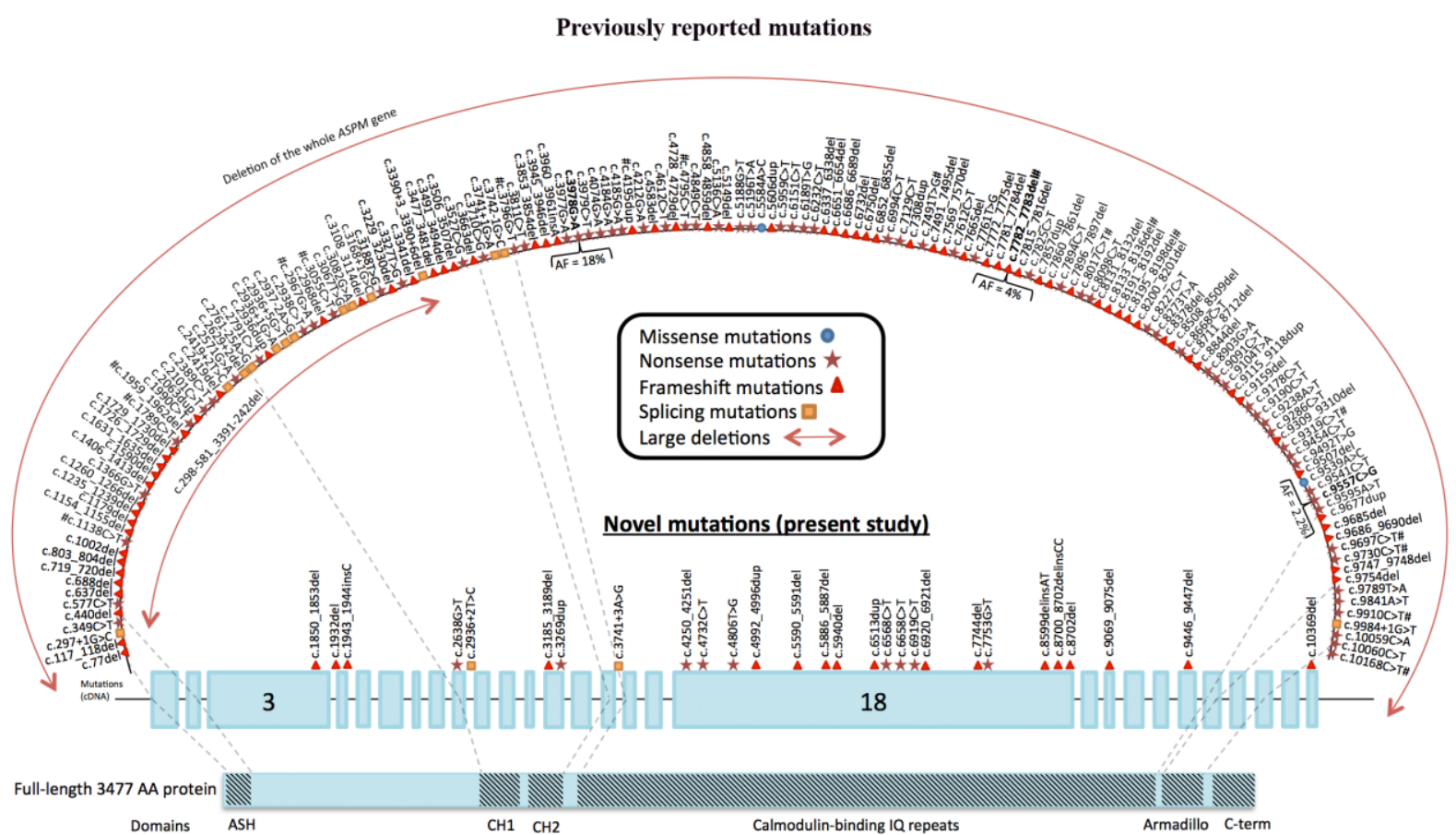

Figure 1

This article is protected by copyright. All rights reserved. 
Figure 2: Geographical distribution of families with ASPM mutations.

The indicated number corresponds to the number of families per country or region.

Total number of families $=321$ (11 families of unknown origin).

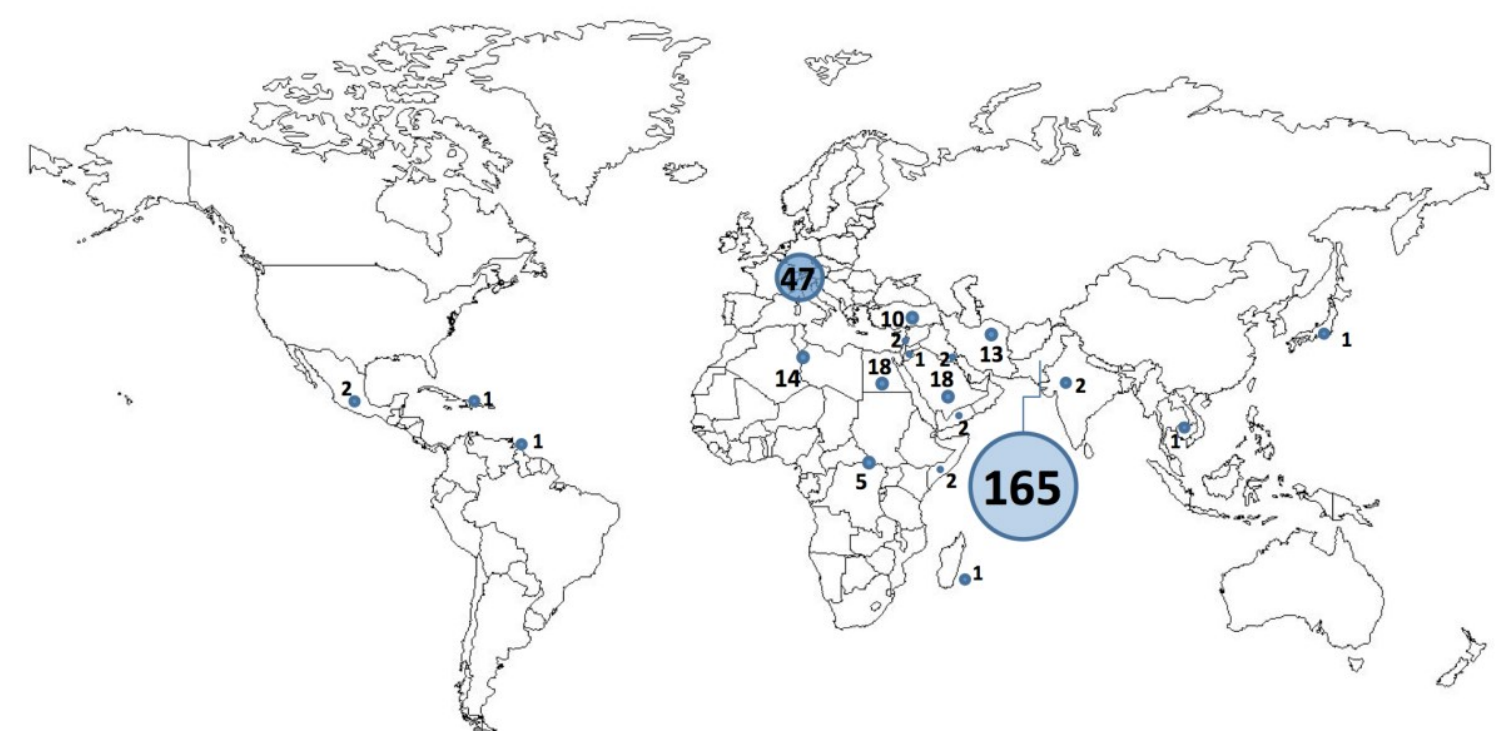

Figure 2 
Figure 3: OFC, length and weight measurements in patients with ASPM mutations in the present study and in the literature

A- OFC and length measurements: Red symbols depict patients from our cohort while black symbols correspond to patients in the literature. Dots represent OFC and lines represent length. Each symbol represents an individual measurement. A single individual may have several measurements at different ages. OFC $=$ occipitofrontal circumference.

B- OFC, length and weight averages at birth and after 6 years

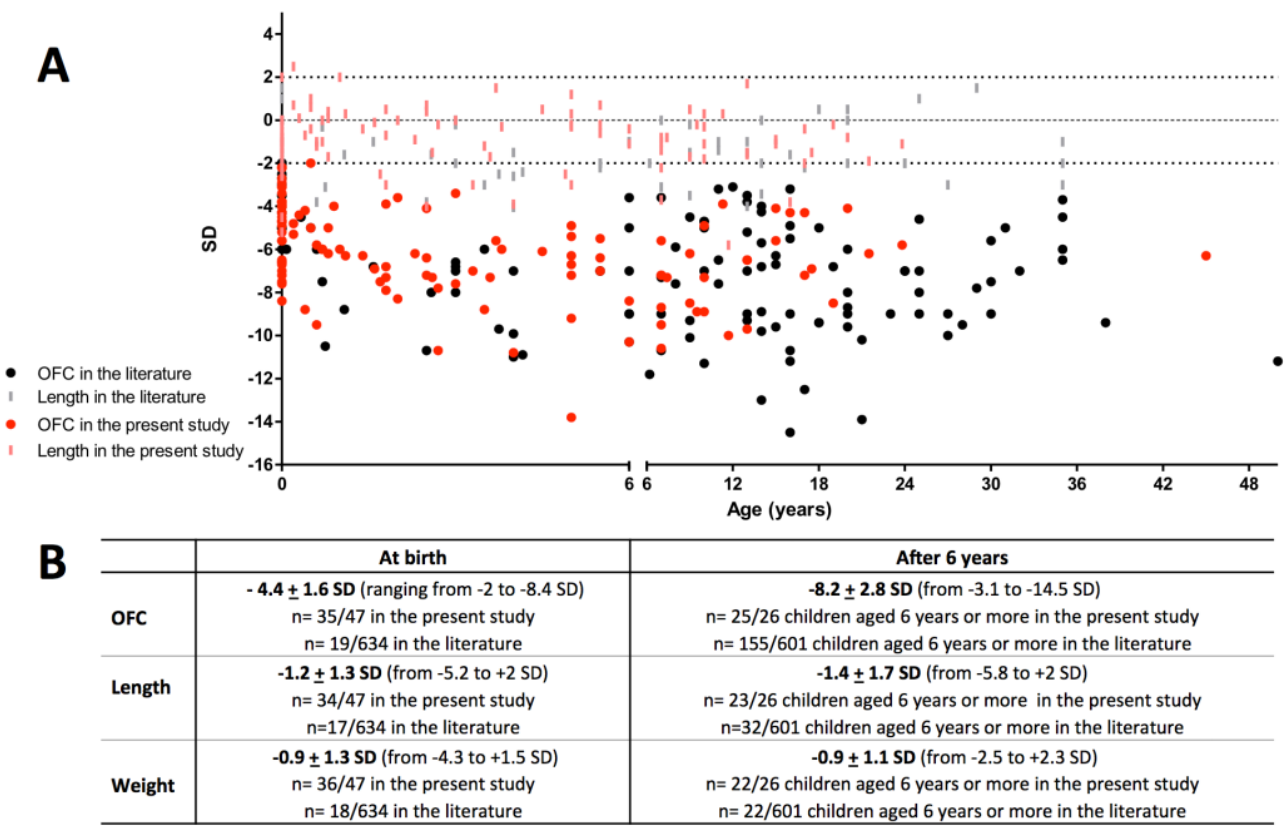

Figure 3

This article is protected by copyright. All rights reserved. 
Figure 4: Intellectual abilities of patients with ASPM mutations

A- Full-scale IQ of ASPM-mutated patients in the literature and in the present study.

Unpaired T-test* $p<0.05$ )

B- Developmental quotient of ASPM-mutated patients

$\mathrm{FSIQ}=$ full scale intellectual quotient; $\mathrm{DQ}=$ developmental quotient.

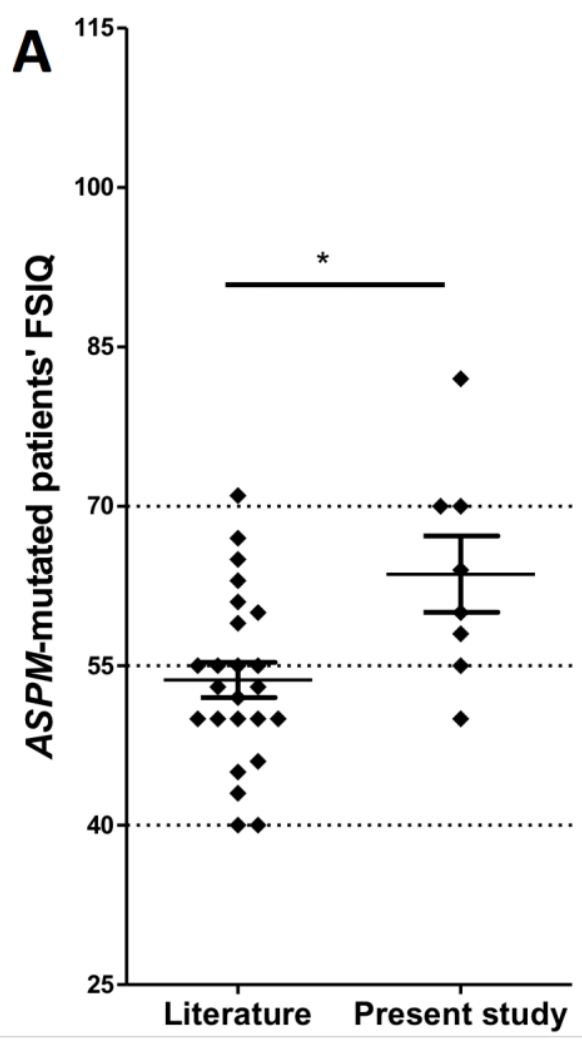

B

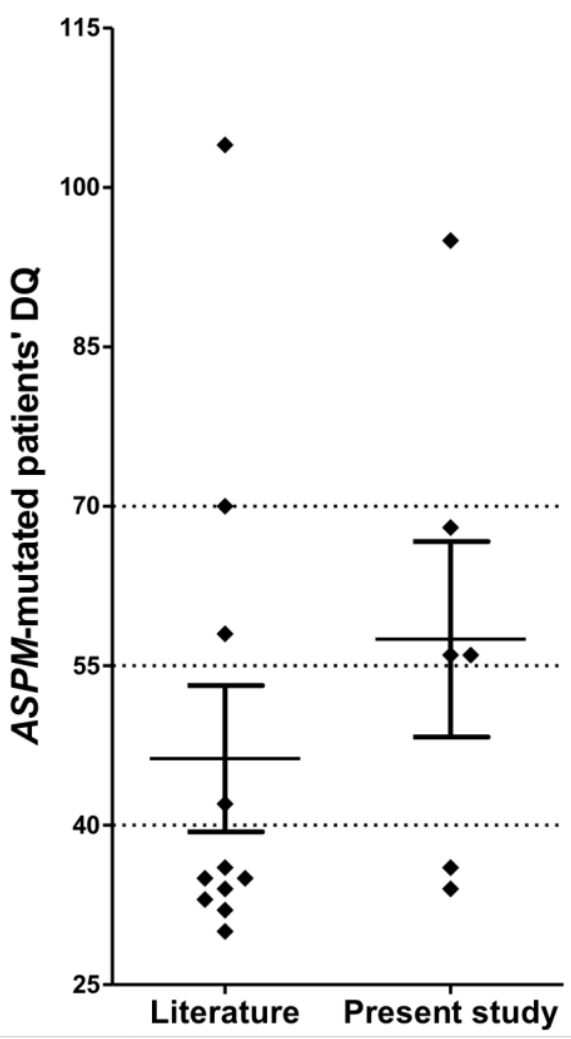

Figure 4 
Figure 5: Typical and atypical neuroradiological features of ASPM-related primary microcephaly

A: patient \#26 (3 years), B: patient \#8 (3.7 years), C: patient \#23.1 (4.3 years) and D: age-matched control, (4 years). From left to right: Sagittal T1- / coronal T1- / axial T1/ coronal T2-weighted images.

Drastic reductions in the volume of both hemispheres affecting the white matter and cerebral cortex and gyral simplification are the main features of ASPM-related primary microcephaly (A, B and C) as compared to age-matched controls. A contrario, the volume of the cerebellum is preserved, as shown in the coronal view. Unilateral or bilateral polymicrogyria may be associated with ASPM-related primary microcephaly, as shown in C (white arrows). 
Tables:

Table 1 - Novel ASPM mutations identified in our cohort, according to HGVS nomenclature recommendations and using the sequence NM_018136.4 as a reference.

\begin{tabular}{|c|c|c|c|c|c|}
\hline Location & $\begin{array}{l}\text { DNA HGVS } \\
\text { nomenclature }\end{array}$ & $\begin{array}{l}\text { Protein HGVS } \\
\text { nomenclature }\end{array}$ & $\begin{array}{l}\text { Protein } \\
\text { effect }\end{array}$ & Families & Origin \\
\hline Exon 3 & c.1850_1853del & p.Thr617Lysfs*30 & Frameshift & $\# 1$ & Moroccan \\
\hline Exon 4 & c.1932del & p.Phe645Serfs*23 & Frameshift & $\# 2$ & Belgian \\
\hline Exon 4 & c.1943_1944insC & p.lle649Asnfs*3 & Frameshift & $\# 3$ & Moroccan \\
\hline Exon 9 & c.2638G $>\mathrm{T}$ & p.Glu880* & Nonsense & $\# 4$ & French \\
\hline Intron 10 & c. $2936+2 T>C$ & p.? & Splicing & $\# 5$ & French \\
\hline Exon 13 & c.3185_3189del & p.Asn1062Argfs*28 & Frameshift & $\# 6$ & Moroccan \\
\hline Exon 13 & c.3269dup & p.Asp1091* & Nonsense & $\# 7$ & Congolese \\
\hline Intron 15 & c. $3741+3 A>G$ & p.? & Splicing & $\# 8$ & African \\
\hline Exon 18 & c.4250_4251del & p.Tyr1417* & Nonsense & $\# 9$ & European \\
\hline Exon 18 & c. $4732 C>T$ & p.Arg1578* & Nonsense & $\# 10$ & French \\
\hline Exon 18 & c.4806T>G & p.Tyr1602* & Nonsense & $\# 11$ & Spanish \\
\hline Exon 18 & c.4992_4996dup & p.Arg1667llefs*12 & Frameshift & $\# 12(n=2)$ & Egyptian \\
\hline Exon 18 & c.5590_5591del & p.Leu1864Serfs*2 & Frameshift & $\# 9$ & European \\
\hline Exon 18 & c.5886_5887del & p.Leu1963Glufs*9 & Frameshift & $\# 13$ & Cameroonian \\
\hline Exon 18 & c.5940del & p.Tyr1981llefs*13 & Frameshift & $\# 14(n=2)$ & Moroccan \\
\hline Exon 18 & c.6513dup & p.Val2172Serfs*7 & Frameshift & $\begin{array}{l}\# 15 \\
\# 16\end{array}$ & $\begin{array}{l}\text { Turkish } \\
\text { Turkish }\end{array}$ \\
\hline Exon 18 & c. $6568 C>T$ & p.Gln2190* & Nonsense & $\begin{array}{c}\# 4 \\
\# 17(n=2) \\
\end{array}$ & \begin{tabular}{|l|} 
French \\
French \\
\end{tabular} \\
\hline Exon 18 & c. $6658 \mathrm{C}>\mathrm{T}$ & p.Gln2220* & Nonsense & $\# 18$ & Tunisian \\
\hline Exon 18 & c.6919C>T & p.Gln2307* & Nonsense & $\# 17(n=2)$ & French \\
\hline Exon 18 & c.6920_6921del & p.GIn2307Leufs*10 & Frameshift & $\# 19$ & French \\
\hline Exon 18 & c.7744del & p.lle2582Serfs*34 & Frameshift & $\# 20$ & Italian \\
\hline Exon 18 & c. $7753 \mathrm{G}>\mathrm{T}$ & p.Glu2585* & Nonsense & $\# 5$ & French \\
\hline Exon 18 & c.8599delinsAT & p.Gln2867llefs*5 & Frameshift & $\# 21$ & French \\
\hline Exon 18 & c.8700_8702delinsCC & p.Lys2900Asnfs*38 & Frameshift & $\# 22$ & Moroccan \\
\hline Exon 18 & c.8702del & p.His2901Leufs*37 & Frameshift & $\begin{array}{l}\# 23(n=2) \\
\# 24(n=3)\end{array}$ & $\begin{array}{l}\text { Egyptian } \\
\text { Moroccan }\end{array}$ \\
\hline Exon 20 & c.9069_9075del & p.His3023Glnfs*2 & Frameshift & $\# 13$ & French \\
\hline Exon 23 & c.9446_9447del & p.Arg3149Metfs*17 & Frameshift & $\# 21$ & French \\
\hline Exon 28 & c.10369del & p.Glu3457Lysfs*13 & Frameshift & $\# 8$ & African \\
\hline
\end{tabular}

This article is protected by copyright. All rights reserved. 
Table 2 - Clinical and radiological features of patients of our cohort (39 families, 47 patients).

\begin{tabular}{|c|c|c|c|c|c|c|c|c|c|c|c|c|c|c|c|}
\hline \multirow{2}{*}{\multicolumn{2}{|c|}{\begin{tabular}{c|c}
$\operatorname{Re}$ & $\mathbf{S}$ \\
$\mathrm{f}$ & $\mathbf{S}$
\end{tabular}}} & \multicolumn{3}{|c|}{ Birth } & \multirow[b]{2}{*}{$\begin{array}{c}\text { MC } \\
\text { on } \\
\text { US }\end{array}$} & \multicolumn{4}{|c|}{ Last follow up } & \multirow[b]{2}{*}{$\begin{array}{c}\mathbf{W} \\
\text { al } \\
\mathbf{k} \\
< \\
1 . \\
5 \\
\text { ye } \\
\text { ar }\end{array}$} & \multirow[b]{2}{*}{$\begin{array}{c}\text { First } \\
\text { sent } \\
\text { ence } \\
<3 \\
\text { year } \\
\text { s }\end{array}$} & \multirow{2}{*}{\begin{tabular}{|c|} 
Epile \\
psy \\
(if \\
yes, \\
age \\
of \\
onset \\
in \\
years \\
)
\end{tabular}} & \multirow[b]{2}{*}{$\begin{array}{c}\text { Abnormalities in brain MRI, } \\
\text { except microcephaly (age in } \\
\text { years) }\end{array}$} & \multirow[b]{2}{*}{$\begin{array}{l}\text { Intellectual } \\
\text { assessment } \\
\text { Test (age in years): } \\
\text { score(s) }\end{array}$} & \multirow[b]{2}{*}{$\begin{array}{l}\text { Others } \\
\text { features }\end{array}$} \\
\hline & & \begin{tabular}{|l|l} 
F & \\
C & L \\
(i & 8 \\
n & \\
S & $S$ \\
D & $S$ \\
) &
\end{tabular} & $\begin{array}{l}\text { Len } \\
\text { gth } \\
\text { (in } \\
\text { SD) }\end{array}$ & $\begin{array}{l}\text { We } \\
\text { ight } \\
\text { (in } \\
\text { SD) }\end{array}$ & & $\begin{array}{c}\mathrm{Ag} \\
\text { e } \\
\text { (in } \\
\text { ye } \\
\text { ars } \\
\text { ) }\end{array}$ & $\begin{array}{c}0 \\
\text { FC } \\
\text { (in } \\
\text { SD } \\
\text { ) }\end{array}$ & $\begin{array}{l}\text { Len } \\
\text { gth } \\
\text { (in } \\
\text { SD) }\end{array}$ & $\begin{array}{l}\text { We } \\
\text { ight } \\
\text { (in } \\
\text { SD) }\end{array}$ & & & & & & \\
\hline \#1 & $\mathrm{M}$ & $\begin{array}{c}- \\
7 . \\
5\end{array}$ & -1 & $\mid-1.6$ & $\mathrm{~T} 2$ & $\begin{array}{c}11 . \\
7\end{array}$ & - & 5.8 & -1.3 & no & no & no & slight cortical atrophy & NAv & hyperactivity \\
\hline$\# 2$ & $\mathrm{M}$ & $\begin{array}{c}- \\
4 . \\
7\end{array}$ & 0 & -0.9 & $\begin{array}{c}N A \\
v\end{array}$ & 9.5 & $\begin{array}{c}- \\
8 . \\
9\end{array}$ & - & -0.7 & $\begin{array}{c}\text { ye } \\
\text { s }\end{array}$ & yes & no & NAv & $\begin{array}{c}\text { WPPSI-R (5.8): } \\
\text { FSIQ=64/ VIQ=81/ } \\
P I Q=52\end{array}$ & hyperactivity \\
\hline \#3 & $\mathrm{F}$ & $\begin{array}{l}- \\
6 . \\
7\end{array}$ & 5.2 & -3.2 & $\begin{array}{c}N A \\
v\end{array}$ & 0.6 & $\begin{array}{c}- \\
5 . \\
8\end{array}$ & -1 & -1.4 & $\begin{array}{c}N \\
A p\end{array}$ & NAp & no & $\begin{array}{c}\text { gyral simplification; thin } \\
\text { corpus callosum; subcortical } \\
\text { hypersignal on T2-weighted } \\
\text { images }(0.6)\end{array}$ & NAp & $\begin{array}{c}\text { hyperpigmen } \\
\text { tation spot }\end{array}$ \\
\hline$\# 4$ & M & $\begin{array}{c}- \\
3 . \\
8\end{array}$ & $\begin{array}{c}- \\
1.5 \\
\end{array}$ & -0.9 & $\begin{array}{c}N A \\
v\end{array}$ & 1.7 & $\begin{array}{c}- \\
7 . \\
5\end{array}$ & 2.5 & -2.8 & no & NAp & no & gyral simplification (0.5) & NAp & $\begin{array}{l}\text { behavioral } \\
\text { disorders }\end{array}$ \\
\hline \#5 & M & $\begin{array}{c}- \\
3 . \\
4 \\
\end{array}$ & 0 & $\begin{array}{c}+1 . \\
1\end{array}$ & no & 20 & $\begin{array}{c}- \\
4 . \\
1\end{array}$ & - & $\begin{array}{c}+0 \\
9\end{array}$ & no & no & no & NAv & NAv & no \\
\hline \#6 & $F$ & $\left|\begin{array}{l}A \\
n\end{array}\right|$ & NA & -1.5 & $\begin{array}{c}N A \\
v\end{array}$ & 7 & \begin{tabular}{|c|} 
\\
10 \\
6 \\
\end{tabular} & 2.2 & -2.5 & no & no & no & $\begin{array}{l}\text { gyral simplification; corpus } \\
\text { callosum hypoplasia (age?) }\end{array}$ & NAv & $\begin{array}{l}\text { congenital } \\
\text { hip } \\
\text { dislocation }\end{array}$ \\
\hline \#7 & $\mathrm{M}$ & \begin{tabular}{|c|}
- \\
6. \\
6
\end{tabular} & $\begin{array}{c}- \\
2.5 \\
\end{array}$ & -2.2 & $\begin{array}{c}N A \\
v\end{array}$ & 7 & $\begin{array}{c}- \\
9 . \\
5\end{array}$ & - & -0.8 & $\begin{array}{c}N \\
A v\end{array}$ & NAv & $\begin{array}{l}\text { yes } \\
(<4)\end{array}$ & NAv & NAv & no \\
\hline$\# 8$ & $\mathrm{M}$ & $\begin{array}{c}- \\
3 . \\
8\end{array}$ & -1 & -0.8 & T3 & 3.7 & $\begin{array}{c}- \\
5 . \\
6\end{array}$ & $\begin{array}{c}+1 \\
5\end{array}$ & $\begin{array}{c}+0 . \\
6\end{array}$ & no & no & no & $\begin{array}{c}\text { ventricular enlargement, } \\
\text { cerebellar hypoplasia, } \\
\text { subcortical hypersignal on T2- } \\
\text { weighted images, elongated } \\
\text { superior cerebellar peduncles } \\
\text { (3.7) } \\
\end{array}$ & $\begin{array}{c}\text { WPPSI-III (3.7): } \\
\text { FSIQ }=60 * / \mathrm{VIQ}=74 / \\
\mathrm{PIQ}=54 / \mathrm{GCL}=85\end{array}$ & no \\
\hline$\# 9$ & $\mathrm{~F}$ & $\begin{array}{c}- \\
3 . \\
8\end{array}$ & $\begin{array}{c}- \\
1.3\end{array}$ & -0.6 & T3 & 4.5 & $\begin{array}{c}- \\
6 . \\
1\end{array}$ & $\begin{array}{c}+0 \\
5\end{array}$ & -0.4 & $\begin{array}{c}N \\
\text { Av }\end{array}$ & NAv & no & gyral simplification (0.7) & Test? (5y): FSIQ = 50 & no \\
\hline $\begin{array}{c}\# 1 \\
0\end{array}$ & $\mathrm{~F}$ & \begin{tabular}{|c|c}
- \\
4. \\
5
\end{tabular} & $\begin{array}{c}- \\
0.2\end{array}$ & -0.7 & T3 & 19 & \begin{tabular}{|c|}
- \\
8. \\
5 \\
\end{tabular} & 0.2 & -0.4 & $\begin{array}{c}\text { ye } \\
s\end{array}$ & no & $\begin{array}{l}\text { yes } \\
(14)\end{array}$ & $\begin{array}{l}\text { gyral simplification, mild } \\
\text { ventricular enlargement; } \\
\text { scaphocephaly }(0.8) \\
\end{array}$ & NAv & $\begin{array}{l}\text { behavioral } \\
\text { disorders }\end{array}$ \\
\hline $\begin{array}{c}\# 1 \\
1\end{array}$ & $F$ & $\begin{array}{l}- \\
2 . \\
7\end{array}$ & $\begin{array}{c}- \\
0.5\end{array}$ & -1 & $\begin{array}{c}N A \\
v\end{array}$ & 3 & $\begin{array}{l}- \\
3 . \\
4\end{array}$ & $\begin{array}{c}\text { NA } \\
\mathrm{v}\end{array}$ & $\begin{array}{c}N A \\
v\end{array}$ & $\begin{array}{c}\text { ye } \\
s\end{array}$ & NAv & no & $\begin{array}{c}\text { gyral simplification; arachnoid } \\
\text { cyst in the posterior fossa; } \\
\text { enlarged Virchow-Robin } \\
\text { spaces (1.7) }\end{array}$ & $\begin{array}{c}\text { Bayley III (3.5): } \\
\quad \mathrm{DQ}=95\end{array}$ & no \\
\hline $\begin{array}{l}\# 1 \\
2 . \\
1\end{array}$ & $\mathrm{~F}$ & $\begin{array}{l}\mathrm{N} \\
\mathrm{A} \\
\mathrm{v}\end{array}$ & $\begin{array}{c}\text { NA } \\
v\end{array}$ & $\begin{array}{c}\mathrm{NA} \\
\mathrm{v}\end{array}$ & $\begin{array}{c}N A \\
v\end{array}$ & 7 & $\begin{array}{c}- \\
7 . \\
2\end{array}$ & 3.7 & -1.9 & $\begin{array}{c}N \\
A v\end{array}$ & NAv & no & $\begin{array}{c}\text { gyral simplification, mild } \\
\text { ventricular enlargement, thin } \\
\text { corpus callosum and } \\
\text { brainstem (7) }\end{array}$ & $\begin{array}{c}\text { Stanford Binet (7): } \\
\mathrm{DQ}=56\end{array}$ & no \\
\hline $\begin{array}{l}\# 1 \\
2 . \\
2\end{array}$ & $\mathrm{M}$ & $\mid \begin{array}{ll}N \\
A \\
v\end{array}$ & $\begin{array}{c}\mathrm{NA} \\
\mathrm{v}\end{array}$ & $\begin{array}{c}\text { NA } \\
\mathrm{v}\end{array}$ & $\begin{array}{c}\text { NA } \\
v\end{array}$ & 0.2 & $\begin{array}{c}- \\
4 . \\
8\end{array}$ & $\begin{array}{c}+2 \\
5\end{array}$ & $\begin{array}{c}+0 \\
2\end{array}$ & $\begin{array}{c}N \\
A p\end{array}$ & NAp & no & $\begin{array}{c}\text { gyral simplification, } \\
\text { ventricular and pericerebral } \\
\text { space enlargement; thin } \\
\text { corpus callosum and } \\
\text { brainstem; myelination delay } \\
\text { in T2-weighted images }(0.3)\end{array}$ & NAp & no \\
\hline
\end{tabular}

This article is protected by copyright. All rights reserved. 


\begin{tabular}{|c|c|c|c|c|c|c|c|c|c|c|c|c|c|c|}
\hline $\begin{array}{c}\# 1 \\
3\end{array}$ & $M \mid \begin{array}{l}- \\
4 . \\
7\end{array}$ & 2.5 & -2 & T3 & 5.5 & \begin{tabular}{|c|}
- \\
6. \\
\end{tabular} & $\begin{array}{c}- \\
0.6 \\
\end{array}$ & -0.4 & $\begin{array}{c}\text { ye } \\
s\end{array}$ & no & no & $\begin{array}{l}\text { white matter hypersignal in } \\
\text { T2-weighted images, } \\
\text { ventricular enlargement (5.5) }\end{array}$ & $\begin{array}{c}\text { WPPSI-III (5.5): } \\
F S I Q=82 * / V I Q=75 / \\
P I Q=90 / G C L=77 \\
\end{array}$ & no \\
\hline \begin{tabular}{c|}
$\# 1$ \\
4. \\
1
\end{tabular} & $M \mid \begin{array}{l}N \\
A \\
v\end{array}$ & NA & $\begin{array}{c}\mathrm{A} A \\
\mathrm{v}\end{array}$ & T3 & 9 & 8. & $\begin{array}{c}+0 . \\
5\end{array}$ & $\begin{array}{c}\text { NA } \\
v\end{array}$ & $\begin{array}{c}\text { ye } \\
\text { s }\end{array}$ & yes & $\begin{array}{l}\text { yes } \\
(0.5)\end{array}$ & NAv & NAv & $\begin{array}{c}\text { hyperactivity } \\
\text {, enuresis }\end{array}$ \\
\hline \begin{tabular}{c|c}
$\# 1$ \\
4. \\
2
\end{tabular} & $M \mid \begin{array}{l}N \\
A \\
v\end{array}$ & NA & $\begin{array}{c}N A \\
v\end{array}$ & T3 & 13 & \begin{tabular}{|c|}
- \\
6. \\
5 \\
\end{tabular} & $\begin{array}{c}+1 . \\
7 \\
\end{array}$ & $\begin{array}{c}\text { NA } \\
\mathrm{v}\end{array}$ & $\begin{array}{c}\text { ye } \\
\text { s }\end{array}$ & yes & $\begin{array}{l}\text { yes } \\
(0.5)\end{array}$ & NAv & NAv & enuresis \\
\hline $\begin{array}{c}\# 1 \\
5\end{array}$ & $F-4$ & $\begin{array}{l}- \\
1.3\end{array}$ & $3-1.5$ & no & 5.5 & \begin{tabular}{|c|}
- \\
5. \\
5
\end{tabular} & +0. & $\begin{array}{c}+1 \\
1\end{array}$ & no & no & no & $\begin{array}{c}\text { gyral simplification, enlarged } \\
\text { subarachnoid spaces, mega } \\
\text { cisterna magna }(0.5)\end{array}$ & NAv & no \\
\hline$\# 1 \mid$ & $\mathrm{M} \mid \begin{array}{l}- \\
6 . \\
5\end{array}$ & 1.6 & $6-0.7$ & T3 & $\begin{array}{c}\mathrm{NA} \\
\mathrm{v}\end{array}$ & $\begin{array}{c}N \\
\text { Av }\end{array}$ & $\begin{array}{c}N A \\
v\end{array}$ & $\begin{array}{c}\mathrm{NA} \\
\mathrm{v}\end{array}$ & $\begin{array}{c}N \\
A v\end{array}$ & NAv & NAv & NAv & NAp & $\begin{array}{c}\text { closed } \\
\text { fontanelles } \\
\text { before birth }\end{array}$ \\
\hline $\begin{array}{c}\# 1 \\
7 . \\
1\end{array}$ & $M \mid \begin{array}{l}- \\
8 . \\
4\end{array}$ & 2.6 & -4 & T3 & $\begin{array}{c}17 . \\
5\end{array}$ & $\begin{array}{c}- \\
6 . \\
9\end{array}$ & $\begin{array}{c}- \\
1.5\end{array}$ & -1.6 & no & no & $\begin{array}{l}\text { yes } \\
\text { (7) }\end{array}$ & $\begin{array}{c}\text { slight left cerebral atrophy; } \\
\text { cervicothoracic syringomyelia } \\
\text { (9) }\end{array}$ & $\begin{array}{c}\text { Borel-Maisonny (4.5) } \\
\quad: \mathrm{DQ}=56\end{array}$ & $\begin{array}{c}\text { spastic } \\
\text { hemiplegic } \\
\text { cerebral } \\
\text { palsy, severe } \\
\text { behavioral } \\
\text { disorders } \\
\end{array}$ \\
\hline \begin{tabular}{c|}
+1 \\
7. \\
2
\end{tabular} & $M \mid \begin{array}{l}- \\
6 . \\
6\end{array}$ & 2.5 & $5^{5}-3.2$ & T3 & 17 & \begin{tabular}{|c|}
- \\
7. \\
\end{tabular} & 0.4 & -1 & no & no & no & no (1) & $\begin{array}{c}\text { Borel-Maisonny (4.4): } \\
\text { DQ }=68\end{array}$ & no \\
\hline \begin{tabular}{|l|}
$\# 1$ \\
8
\end{tabular} & $\mathrm{M} \mid \begin{array}{l}- \\
3 . \\
8\end{array}$ & -1 & $\begin{array}{c}+0 . \\
2\end{array}$ & \begin{tabular}{|c|}
$\mathrm{T} 2$ \\
$\& \mathrm{~T}$ \\
3 \\
\end{tabular} & 1 & -6 & +2 & +1 & \begin{tabular}{c|c} 
ye & 1 \\
s & 1
\end{tabular} & NAp & no & no (1) & NAp & $\begin{array}{l}\text { behavioral } \\
\text { disorders }\end{array}$ \\
\hline \begin{tabular}{c|}
$\# 1$ \\
9
\end{tabular} & $\mathrm{~F} \mid \begin{array}{l}- \\
7 . \\
2\end{array}$ & 1.1 & $1-0.3$ & no & 3.3 & -7 & -3 & -2.2 & no & no & $\begin{array}{c}\text { yes } \\
(1.5)\end{array}$ & $\begin{array}{l}\text { gyral simplification, thin } \\
\text { corpus callosum, pineal cyst, } \\
\text { large arachnoid cyst in the } \\
\text { posterior fossa }(0.3)\end{array}$ & NAv & $\begin{array}{l}\text { left middle } \\
\text { ear } \\
\text { hypoplasia, } \\
\text { behavioral } \\
\text { disorders }\end{array}$ \\
\hline $\begin{array}{c}\# 2 \\
0\end{array}$ & $\mathrm{M} \mid \begin{array}{l}- \\
4 . \\
3\end{array}$ & 0.5 & 0 & \begin{tabular}{|c|}
$T 2$ \\
$\& T$ \\
3 \\
\end{tabular} & 7 & \begin{tabular}{|c|}
- \\
5. \\
6 \\
\end{tabular} & $\begin{array}{c}- \\
1.4\end{array}$ & -1.7 & $\begin{array}{c}\text { ye } \\
\text { s }\end{array}$ & no & $\begin{array}{l}\text { yes } \\
\text { (6) }\end{array}$ & $\begin{array}{l}\text { gyral simplification, } \\
\text { polymicrogyria in fronto- } \\
\text { insular region (7) }\end{array}$ & Test? (9.3): $\mathrm{DQ}=34$ & no \\
\hline$\# 2$ & $M \mid \begin{array}{l}N \\
A \\
v\end{array}$ & $\begin{array}{l}\text { NA } \\
\text { v }\end{array}$ & $\begin{array}{l}\mathrm{NA} \\
\mathrm{v}\end{array}$ & $\begin{array}{c}N A \\
v\end{array}$ & 45 & \begin{tabular}{|c|}
- \\
6. \\
3
\end{tabular} & $\begin{array}{c}N A \\
v\end{array}$ & $\begin{array}{c}N A \\
v\end{array}$ & no & NAv & $\begin{array}{l}\text { yes } \\
\text { (7) }\end{array}$ & $\begin{array}{l}\text { gyral simplification; mild } \\
\text { ventricular enlargement; } \\
\text { mega cisterna magna; } \\
\text { hypersignal of the temporal } \\
\text { poles in T2 -weighted images; } \\
\text { thin brainstem; major vermis } \\
\text { and cerebellar atrophy (45) }\end{array}$ & NAv & $\begin{array}{c}\text { Ceroid } \\
\text { lipofuscinosis } \\
\text { with } \\
\text { identified } \\
\text { CLN3 } \\
\text { mutations } \\
\text { (retinitis } \\
\text { pigmentosa) }\end{array}$ \\
\hline \begin{tabular}{|l}
$\# 2$ \\
2
\end{tabular} & $\mathrm{~F}\left(\begin{array}{l}- \\
2 . \\
2\end{array}\right.$ & +2 & $2 N A$ & no & 15 & \begin{tabular}{|c|} 
\\
4. \\
1
\end{tabular} & 1.1 & $\begin{array}{c}+2 \\
3\end{array}$ & $\begin{array}{c}\text { ye } \\
\text { s }\end{array}$ & yes & $\begin{array}{l}\text { yes } \\
\text { (15) }\end{array}$ & no & NAv & no \\
\hline $\begin{array}{c}\# 2 \\
3 . \\
1\end{array}$ & $M \mid \begin{array}{l}N \\
A \\
v\end{array}$ & $\begin{array}{l}\text { NA } \\
\text { v }\end{array}$ & $\begin{array}{c}\mathrm{A} A \\
\mathrm{v}\end{array}$ & $\begin{array}{c}N A \\
v\end{array}$ & 4 & \begin{tabular}{|c|}
- \\
10 \\
.8
\end{tabular} & $\begin{array}{c}- \\
3.9\end{array}$ & -3.1 & no & NAv & no & \begin{tabular}{|c|} 
thick frontal gyri, gyral \\
simplification; thick corpus \\
callosum; extensive bilateral \\
posterior polymicrogyria (4.3)
\end{tabular} & NAv & $\begin{array}{c}\text { spastic } \\
\text { tetraplegia }\end{array}$ \\
\hline $\begin{array}{c}\# 2 \\
3 . \\
2\end{array}$ & $M \mid \begin{array}{l}N \\
A \\
v\end{array}$ & $\begin{array}{l}\text { NA } \\
\text { v }\end{array}$ & $\begin{array}{c}A \\
\mathrm{~A} A \\
\mathrm{v}\end{array}$ & $\begin{array}{c}N A \\
v\end{array}$ & 6 & $\begin{array}{c}- \\
8 . \\
4\end{array}$ & 1.1 & -0.6 & $\begin{array}{c}\mathrm{N} \\
\mathrm{Av}\end{array}$ & no & no & $\begin{array}{c}\text { thick frontal gyri, gyral } \\
\text { simplification; thick corpus } \\
\text { callosum. hypersignal of } \\
\text { temporal poles in T2-weighted } \\
\text { images (6.5) }\end{array}$ & Test? (age?): DQ = 36 & $\begin{array}{l}\text { behavioral } \\
\text { disorders }\end{array}$ \\
\hline \begin{tabular}{c|}
$\# 2$ \\
4. \\
1
\end{tabular} & $F \mid \begin{array}{l}N \\
A \\
V\end{array}$ & $\begin{array}{c}\text { NA } \\
v\end{array}$ & $\begin{array}{c}N A \\
v\end{array}$ & no & 17 & $\begin{array}{c}- \\
4 . \\
3\end{array}$ & -2 & -1.2 & $\begin{array}{c}\text { ye } \\
\text { s }\end{array}$ & no & no & NAv & NAv & no \\
\hline \begin{tabular}{c|}
$\# 2$ \\
4. \\
2
\end{tabular} & $F \mid \begin{array}{l}N \\
A \\
V\end{array}$ & $\begin{array}{c}\text { NA } \\
\text { v }\end{array}$ & $\begin{array}{c}\mathrm{NA} \\
\mathrm{v}\end{array}$ & T3 & 9 & $\begin{array}{l}- \\
6 . \\
2\end{array}$ & $\begin{array}{c}- \\
1.7\end{array}$ & -1.9 & $\begin{array}{c}\text { ye } \\
\text { s }\end{array}$ & no & no & NAv & NAv & no \\
\hline
\end{tabular}

This article is protected by copyright. All rights reserved. 


\begin{tabular}{|c|c|c|c|c|c|c|c|c|c|c|c|c|c|c|c|}
\hline $\begin{array}{c}\# 2 \\
4 . \\
3\end{array}$ & $\mathrm{M}$ & $\begin{array}{l}N \\
A \\
V\end{array}$ & $\begin{array}{c}\text { NA } \\
\mathrm{v}\end{array}$ & -4.3 & T3 & 7 & $\begin{array}{c}- \\
8 . \\
7\end{array}$ & $\begin{array}{c}N A \\
v\end{array}$ & -2 & no & no & no & Pachygyria & NAv & $\begin{array}{c}\text { vertical } \\
\text { nystagmus }\end{array}$ \\
\hline $\begin{array}{c}\# 2 \\
5\end{array}$ & $\mathrm{~F}$ & $\begin{array}{l}- \\
7 . \\
6\end{array}$ & $\begin{array}{c}\text { NA } \\
v\end{array}$ & -1.7 & T3 & 0.6 & $\begin{array}{l}9 . \\
5\end{array}$ & $\begin{array}{c}- \\
1.2\end{array}$ & -2 & $\begin{array}{c}N \\
A p\end{array}$ & NAp & no & gyral simplification (0.6) & NAp & $\begin{array}{c}\text { hypertonia, } \\
\text { hyperpigmen } \\
\text { tation spot }\end{array}$ \\
\hline $\begin{array}{c}\# 2 \\
6\end{array}$ & $\mathrm{M}$ & -7 & 4.5 & -3 & T3 & 2.7 & $\begin{array}{c}- \\
10 \\
.7\end{array}$ & $\begin{array}{c}\text { NA } \\
\mathrm{v}\end{array}$ & -1.6 & no & NAp & no & $\begin{array}{c}\text { gyral simplification; anterior } \\
\text { pachygyria; mega cisterna } \\
\text { magna; short splenium of the } \\
\text { corpus callosum and } \\
\text { cerebellar hypoplasia; } \\
\text { relatively large mammillary } \\
\text { bodies (3) } \\
\end{array}$ & NAp & $\begin{array}{c}\text { behavioral } \\
\text { disorders, } \\
\text { pyramidal } \\
\text { syndrome, } \\
\text { oral } \\
\text { dyspraxia }\end{array}$ \\
\hline $\begin{array}{c}\# 2 \\
7\end{array}$ & $\mathrm{M}$ & 4. & 0 & -1.3 & no & 13 & $\begin{array}{l}- \\
9 . \\
7\end{array}$ & $\begin{array}{c}- \\
1.6\end{array}$ & -1.3 & no & no & $\begin{array}{l}\text { yes } \\
(1.5)\end{array}$ & $\begin{array}{c}\text { Pronounced gyral } \\
\text { simplification } \\
\text { (microlissencephaly?); corpus } \\
\text { callosum hypoplasia }\end{array}$ & NAv & $\begin{array}{c}\text { hypo/hyperp } \\
\text { igmentation } \\
\text { spots, } \\
\text { behavioral } \\
\text { disorders }\end{array}$ \\
\hline $\begin{array}{c}\# 2 \\
8\end{array}$ & $\mathrm{~F}$ & $\begin{array}{c}- \\
2 . \\
2\end{array}$ & $\begin{array}{c}- \\
0.8\end{array}$ & $\begin{array}{c}+1 . \\
5\end{array}$ & T3 & 5 & $\begin{array}{c}- \\
4 . \\
9\end{array}$ & 0.3 & -0.3 & $\begin{array}{c}\text { ye } \\
\text { s }\end{array}$ & no & no & gyral simplification (2) & NAv & $\begin{array}{l}\text { behavioral } \\
\text { disorders }\end{array}$ \\
\hline $\begin{array}{c}\# 2 \\
9\end{array}$ & $\mathrm{M}$ & $\begin{array}{c}\mathrm{N} \\
\mathrm{A} \\
\mathrm{V}\end{array}$ & $\begin{array}{c}\text { NA } \\
\mathrm{v}\end{array}$ & $\begin{array}{c}N A \\
v\end{array}$ & no & 3 & $\begin{array}{l}- \\
7 . \\
6\end{array}$ & 0 & -0.8 & $\begin{array}{c}\text { ye } \\
\text { s }\end{array}$ & no & no & no (2) & NAv & $\begin{array}{l}\text { behavioral } \\
\text { disorders }\end{array}$ \\
\hline $\begin{array}{c}\# 3 \\
0\end{array}$ & $\mathrm{M}$ & \begin{tabular}{|c|} 
\\
5. \\
6 \\
\end{tabular} & -2 & -1.8 & T3 & 3.5 & $\begin{array}{l}- \\
8 . \\
8\end{array}$ & $\begin{array}{c}- \\
1.2\end{array}$ & -1.2 & $\begin{array}{c}\text { ye } \\
\text { s }\end{array}$ & no & no & gyral simplification (2.6) & $\begin{array}{l}\text { WPPSI-III (3.5): } \\
\mathrm{FSIQ}=55 / \mathrm{VIQ}=62 / \\
\mathrm{PIQ}=57 / \mathrm{GCL}=65\end{array}$ & \begin{tabular}{|c|}
$\begin{array}{c}\text { hypo/hyperp } \\
\text { igmentation } \\
\text { spots }\end{array}$ \\
\end{tabular} \\
\hline $\begin{array}{c}\# 3 \\
1\end{array}$ & $\mathrm{M}$ & \begin{tabular}{|c|}
- \\
3. \\
8
\end{tabular} & 0.5 & -0.1 & T3 & 2.3 & $\begin{array}{l}- \\
6 . \\
2\end{array}$ & $\begin{array}{c}- \\
0.9\end{array}$ & -0.2 & $\begin{array}{c}\text { ye } \\
\mathrm{s}\end{array}$ & NAp & no & $\begin{array}{l}\text { gyral simplification, thin } \\
\text { corpus callosum }(0.1)\end{array}$ & NAp & $\begin{array}{c}\text { hypotonia, } \\
\text { behavioral } \\
\text { disorders } \\
\end{array}$ \\
\hline $\begin{array}{c}\# 3 \\
2 . \\
1\end{array}$ & $F$ & -4 & 1.9 & -1.8 & no & $\begin{array}{c}21 . \\
5\end{array}$ & $\begin{array}{l}- \\
6 . \\
2\end{array}$ & $\begin{array}{c}- \\
1.9\end{array}$ & -0.3 & $\begin{array}{c}\text { ye } \\
\text { s }\end{array}$ & no & no & $\begin{array}{c}\text { gyral simplification; vermis } \\
\text { hypoplasia (9) }\end{array}$ & Test? (12):FSIQ =70 & $\begin{array}{c}\text { scoliosis, } \\
\text { hyperpigmen } \\
\text { tation spot, } \\
\text { inverted } \\
\text { nipples } \\
\end{array}$ \\
\hline $\begin{array}{c}\# 3 \\
2 . \\
2\end{array}$ & $\mathrm{~F}$ & $\begin{array}{c}- \\
2 . \\
2\end{array}$ & 2.4 & -0.6 & no & $\begin{array}{c}23 . \\
8\end{array}$ & $\begin{array}{l}- \\
5 . \\
8\end{array}$ & $\begin{array}{c}- \\
1.1\end{array}$ & -0.4 & $\begin{array}{c}\text { ye } \\
\text { s }\end{array}$ & no & no & slight cortical atrophy (1) & Test? (10):FSIQ =70 & $\begin{array}{c}\text { scoliosis, } \\
\text { hypopigment } \\
\text { ation spot, } \\
\text { inverted } \\
\text { nipples }\end{array}$ \\
\hline $\begin{array}{c}\# 3 \\
3 . \\
1\end{array}$ & $\mathrm{M}$ & \begin{tabular}{|c|}
- \\
5. \\
6
\end{tabular} & 2.5 & -2.4 & T3 & 2.7 & $\begin{array}{l}- \\
7 . \\
8\end{array}$ & $\begin{array}{c}- \\
0.2\end{array}$ & -1.1 & $\begin{array}{c}\text { ye } \\
\text { s }\end{array}$ & NAp & no & gyral simplification (0.2) & NAp & $\begin{array}{l}\text { abnormality } \\
\text { of helix }\end{array}$ \\
\hline $\begin{array}{c}\# 3 \\
3 . \\
2\end{array}$ & $\mathrm{~F}$ & $\begin{array}{c}- \\
4 . \\
9\end{array}$ & 1.9 & -0.9 & T3 & 0.2 & $\begin{array}{l}- \\
5 . \\
3\end{array}$ & $\begin{array}{c}+0 . \\
7\end{array}$ & -0.4 & $\begin{array}{c}N \\
A p\end{array}$ & NAp & no & $\begin{array}{l}\text { gyral simplification; thin } \\
\text { corpus callosum }(0.2)\end{array}$ & NAp & $\begin{array}{l}\text { abnormality } \\
\text { of helix }\end{array}$ \\
\hline $\begin{array}{c}\# 3 \\
4\end{array}$ & $\mathrm{M}$ & 2. & -1 & -1.1 & $\begin{array}{c}N A \\
v\end{array}$ & $\begin{array}{c}11 . \\
3\end{array}$ & $\begin{array}{l}- \\
3 . \\
9\end{array}$ & $\begin{array}{c}+0 . \\
3\end{array}$ & $\begin{array}{c}+0 . \\
1\end{array}$ & $\begin{array}{c}\text { ye } \\
\mathrm{s}\end{array}$ & no & no & $\begin{array}{c}\text { gyral simplification; enlarged } \\
\text { Virchow-Robin spaces; mega } \\
\text { cisterna magna (5) }\end{array}$ & $\begin{array}{c}\text { WPPSI-IV (7.2): } \\
F S I Q=58^{*} / \mathrm{VCl}=86 / \\
\mathrm{FRI}=63 / \mathrm{WMI}=56 / \\
\mathrm{PSI}=66\end{array}$ & $\begin{array}{l}\text { behavioral } \\
\text { disorders }\end{array}$ \\
\hline $\begin{array}{c}\# 3 \\
5\end{array}$ & $\mathrm{~F}$ & $\begin{array}{c}- \\
3 . \\
1\end{array}$ & 0.8 & $\begin{array}{c}+0 . \\
1\end{array}$ & T3 & 1.4 & $\begin{array}{l}- \\
6 \\
3\end{array}$ & $\begin{array}{c}- \\
0.4\end{array}$ & -1 & $\begin{array}{c}N \\
A p\end{array}$ & NAp & no & $\begin{array}{c}\text { gyral simplification; thin } \\
\text { corpus callosum; enlarged } \\
\text { Virchow-Robin spaces }(0.3)\end{array}$ & NAp & $\begin{array}{l}\text { behavioral } \\
\text { disorders }\end{array}$ \\
\hline $\begin{array}{c}\# 3 \\
6\end{array}$ & $\mathrm{M}$ & \begin{tabular}{|c}
- \\
4. \\
3
\end{tabular} & 1.3 & -1.3 & $\begin{array}{c}N A \\
v\end{array}$ & 16 & $\begin{array}{c}- \\
4 . \\
3\end{array}$ & $\begin{array}{c}- \\
3.8\end{array}$ & -2.5 & $\begin{array}{c}\text { ye } \\
\text { s }\end{array}$ & yes & no & $\begin{array}{l}\text { hypersignal of the thalamus in } \\
\text { T2-weighted images (13.8) }\end{array}$ & NAv & no \\
\hline $\begin{array}{c}\# 3 \\
7\end{array}$ & $F$ & -4 & 0.8 & -0.9 & no & 13 & $\begin{array}{c}- \\
6 . \\
5\end{array}$ & 1.5 & -1 & no & no & $\begin{array}{c}\text { parox } \\
\text { ysmal } \\
\text { event } \\
\text { s }\end{array}$ & $\begin{array}{c}\text { gyral simplification, } \\
\text { scaphocephaly; enlarged } \\
\text { Virchow-Robin spaces, mild } \\
\text { enlarged ventricles (11) }\end{array}$ & NAv & scoliosis \\
\hline \#3 & $\mathrm{M}$ & - & - & -0.8 & T3 & 3.6 & - & - & -2.5 & ye & no & no & gyral simplification (fetal) & $\mathrm{NAv}$ & NAv \\
\hline
\end{tabular}

This article is protected by copyright. All rights reserved. 


\begin{tabular}{|c|c|c|c|c|c|c|c|c|c|c|c|c|c|c|c|}
\hline 8 & & $\begin{array}{l}5 . \\
2\end{array}$ & 1.5 & & & & $\begin{array}{l}7 . \\
3\end{array}$ & 1.7 & & $\mathrm{~s}$ & & & & & \\
\hline $\begin{array}{c}\# 3 \\
9\end{array}$ & $F$ & $\begin{array}{c}- \\
3 . \\
1\end{array}$ & $\begin{array}{c}- \\
2.2\end{array}$ & $\begin{array}{c}+0 . \\
1\end{array}$ & T3 & 7.4 & $\begin{array}{l}7 . \\
3\end{array}$ & $\begin{array}{c}- \\
0.8\end{array}$ & -0.5 & $\begin{array}{c}\text { ye } \\
\text { s }\end{array}$ & no & no & no (2) & NAv & $\begin{array}{l}\text { coarse facial } \\
\text { features, } \\
\text { retrognathia }\end{array}$ \\
\hline
\end{tabular}

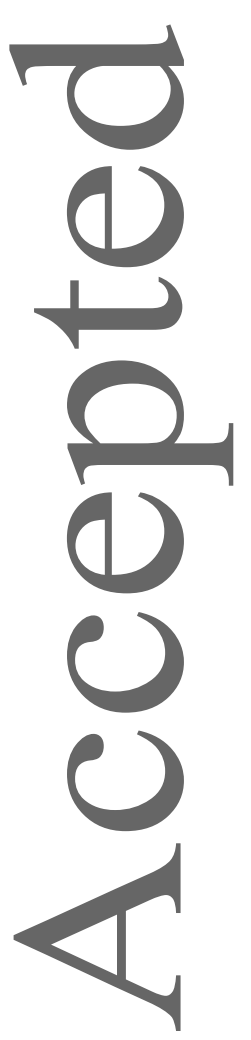

This article is protected by copyright. All rights reserved. 